\title{
The effect of source of supplemental dietary calcium and magnesium in the peripartum period, and level of dietary magnesium postpartum, on mineral status, performance, and energy metabolites in multiparous Holstein cows
}

\author{
B. M. Leno, ${ }^{*}$ S. E. LaCount, ${ }^{*}$ C. M. Ryan, ${ }^{*}$ D. Briggs, $†$ M. Crombie, $\ddagger$ and T. R. Overton ${ }^{* 1}$ \\ *Department of Animal Science, Cornell University, Ithaca, NY 14853 \\ †Papillon Agricultural Company Inc., Easton, MD 21601 \\ $\ddagger$ IMIN-AD Inc., Winnemucca, NV 89445
}

\section{ABSTRACT}

The objective of this study was to determine the effects of feeding different supplemental sources of $\mathrm{Ca}$ and $\mathrm{Mg}$ in the peripartum period, and different dietary levels of $\mathrm{Mg}$ postpartum, on plasma mineral status, performance, and aspects of energy metabolism in transition dairy cows. Multiparous Holstein cows $(\mathrm{n}=41)$ were used in a completely randomized design with a 2 $\times 2$ factorial arrangement of treatments starting at 28 $\mathrm{d}$ before expected parturition. Main effects were source assignments $(\mathrm{CS}=$ common sources of supplemental $\mathrm{Ca}$ and $\mathrm{Mg}$, or $\mathrm{MA}=\mathrm{a}$ blend of common and commercial mineral sources with supplemental minerals primarily from a commercial $\mathrm{Ca}-\mathrm{Mg}$ dolomite source; MIN-AD, Papillon Agricultural Company Inc., Easton, MD) beginning at $21 \mathrm{~d}$ before due date; cows were further randomized within source treatments to 1 of 2 levels of $\mathrm{Mg}$ supplementation ( $\mathrm{LM}=$ formulated postpartum diet $\mathrm{Mg}$ at $0.30 \%$ of dry matter (DM), or $\mathrm{HM}$ $=$ formulated postpartum diet $\mathrm{Mg}$ at $0.45 \%$ of $\mathrm{DM}$ ) beginning within $1 \mathrm{~d}$ after parturition. Final treatment groups included the following: common source, low $\mathrm{Mg}$ (CS-LM, $\mathrm{n}=11$ ); common source, high $\mathrm{Mg}$ (CS-HM, $\mathrm{n}=11)$; MIN-AD, low Mg (MA-LM, $\mathrm{n}=10)$; and MIN-AD, high Mg (MA-HM, $\mathrm{n}=9$ ). Treatment diets were fed and data collected through $42 \mathrm{~d}$ in milk. Postpartum plasma $\mathrm{Mg}$ concentrations tended to be higher for cows fed HM and cows fed CS, but no effects were observed on peripartum plasma Ca concentrations. Peripartum plasma $\mathrm{P}$ concentrations were higher for cows fed MA. Dry matter intake (DMI) in the prepartum period was higher for cows fed MA (CS $=15.9$ vs. $\mathrm{MA}=16.8 \mathrm{~kg} / \mathrm{d}$ ) and postpartum DMI was higher in

Received February 21, 2017.

Accepted May 1, 2017.

${ }^{1}$ Corresponding author: tro2@cornell.edu some groups depending on week. Plasma nonesterified fatty acid concentrations were lower for cows fed MA during both the prepartum and postpartum periods. A source by level interaction was observed for postpartum plasma $\beta$-hydroxybutyrate (BHB) concentrations such that cows fed CS-LM had numerically higher BHB and cows fed MA-LM had numerically lower BHB (geometric means; $\mathrm{CS}-\mathrm{LM}=7.9, \mathrm{CS}-\mathrm{HM}=6.9, \mathrm{MA}-\mathrm{LM}=6.3$, and $\mathrm{MA}-\mathrm{HM}=7.3 \mathrm{mg} / \mathrm{dL}$ ) than cows fed the other 2 treatments. Higher milk fat yield, milk fat content, and fat- and energy-corrected yield during wk 1 for cows fed MA resulted in source by week interactions for these outcomes. This study demonstrated that varying supplemental Ca and $\mathrm{Mg}$ sources and feeding rates had minimal effect on plasma Ca status despite differences in plasma $\mathrm{Mg}$ and $\mathrm{P}$ concentrations. Effects on DMI and plasma energy metabolites suggest an opportunity for strategic use of mineral sources in the transition period to promote metabolic health.

Key words: transition cow, magnesium, calcium

\section{INTRODUCTION}

Hypocalcemia is a disorder in which blood Ca concentrations are compromised as the result of inadequate adaptation to the lactational demands for $\mathrm{Ca}$ that begin at the onset of colostrum production in dairy cows (Ramberg et al., 1970). Recent research has determined that 11 to $25 \%$ of first lactation animals and 42 to $60 \%$ of multiparous cows can be categorized as having subclinical hypocalcemia (SCH; low blood Ca with no clinical signs of hypocalcemia) in the day after parturition (Reinhardt et al., 2011; Caixeta et al., 2015). Martinez et al. (2012) demonstrated an association between SCH and compromised energy metabolism, risk of uterine disease, and delayed reproduction. Additional work described similar associations with reproduction (Chapinal et al., 2012) and energy metabolism (Chamberlin et al., 2013) and has further demonstrated 
increased risk for displaced abomasum and early lactation culling (Chapinal et al., 2011; Roberts et al., 2012) as well as decreased early lactation milk production (Chapinal et al., 2012) in cows with SCH. Taken together, the body of evidence suggests that $\mathrm{SCH}$ is a highly prevalent and costly disorder.

Magnesium is known to be an important mineral in the homeostatic pathway for regulating blood $\mathrm{Ca}$ based on work conducted in cows (van Mosel et al., 1990, 1991) and humans (Rude et al., 1978, 1985). Feeding higher concentrations of dietary $\mathrm{Mg}$ prepartum (0.45- $0.50 \%$ of $\mathrm{DM})$ has become common practice to aid in prevention of hypocalcemia at parturition and was supported by a meta-analysis conducted by Lean et al. (2006). Decreased blood Mg concentrations during the week after parturition have been reported in several published studies (Green et al., 1981; Shappell et al., 1987; Ramos-Nieves et al., 2009; Kronqvist et al., 2011); however, little work has been done to understand the causes and consequences of this blood $\mathrm{Mg}$ pattern. Theoretically, feeding higher dietary rates of $\mathrm{Mg}$ postpartum to increase blood $\mathrm{Mg}$ may help in the recovery of plasma $\mathrm{Ca}$ because plasma Ca concentrations have been shown to take several days to return to prepartum levels (Ramos-Nieves et al., 2009). To the authors' knowledge, feeding varying rates of $\mathrm{Mg}$ postpartum to support the recovery of blood Ca has not been investigated.

Dietary mineral source may have effects on mineral status due to variation in bioavailability, which can be affected by calcination temperature, chemical structure, and particle size (Moore et al., 1971; Jesse et al., 1981; Van Ravenswaay et al., 1989; Xin et al., 1989). Further, mineral sources of different chemical structures have been shown to have varying buffering capacities (Schaefer et al., 1982), which may aid in transition period intake and performance where diet transitions have been shown to challenge rumen health (Penner et al., 2007). Investigation of the performance of cows in the transition period fed varying supplemental mineral sources may provide evidence for strategic use of mineral sources to promote successful diet transitions.

The objectives of this experiment were to determine the effects of dietary source of supplemental $\mathrm{Ca}$ and $\mathrm{Mg}$, and postpartum dietary level of $\mathrm{Mg}$, on intake, performance, and aspects of energy and mineral metabolism in multiparous Holstein cows. We hypothesized that plasma mineral status would be altered by feeding supplemental minerals from a commercial $\mathrm{Ca}-\mathrm{Mg}$ dolomite and feeding a higher rate of dietary $\mathrm{Mg}$ postpartum. If plasma mineral status was improved by either factor, it was hypothesized that intake and performance would also be improved in those cows.

\section{MATERIALS AND METHODS}

\section{Study Population, Experimental Design, and Treatments}

All animal protocols were approved by the Cornell University Institutional Animal Care and Use Committee. Animals were enrolled in the experiment between May and July of 2015. Multiparous Holstein cows (n $=47$ ) were enrolled in a completely randomized design with a $2 \times 2$ factorial arrangement of treatments starting at $28 \mathrm{~d}$ before expected parturition. Cows were fed a control diet for $1 \mathrm{wk}$, and at $21 \mathrm{~d}$ before expected parturition cows were assigned randomly to treatment with randomization restricted to balance for parity group (second vs. third and greater lactation) and previous 305-d mature-equivalent milk production. During the prepartum period, cows were randomized to 1 of 2 source treatments in which supplemental dietary Ca and $\mathrm{Mg}$ were provided primarily from common sources [Mg oxide (BRAZAMAG, Timab Industries, Dinard, France) and limestone; CS] or from a blend of common and commercial mineral sources with supplemental minerals primarily from a commercial $\mathrm{Ca}-\mathrm{Mg}$ dolomite source (MIN-AD, Papillon Agricultural Company, Easton, MD; MA). At the next feeding that occurred after parturition, both CS and MA groups were further randomized into 2 groups within their source treatments in which one received diets formulated to contain $\mathrm{Mg}$ at about NRC (2001) recommendations (CS-LM and MA-LM $=0.30 \%$ of DM) or at a higher rate (CS-HM and MA-HM $=0.45 \%$ of DM). Cows were fed experimental diets and data were collected through 42 DIM. The target study population was 40 cows total. Sample size determination was based on detecting biologically important differences in plasma mineral concentrations in the week following parturition. The average and standard deviations for these outcomes were based on previous work conducted in our group for a treatment group fed similar prepartum rations (Leno et al., 2017). With $\alpha=0.05$ and $\beta=0.20$, the detectable difference in wk 1 for $\mathrm{Ca}, \mathrm{Mg}$, and $\mathrm{P}$ for the main effects of source and level were $0.27,0.11$, and $0.30 \mathrm{mmol} / \mathrm{L}$, respectively. Criteria for removal from the trial included twin births $(\mathrm{n}=5)$ and calving with less than $10 \mathrm{~d}$ fed the experimental prepartum diet $(\mathrm{n}=1)$. Cows excluded before the end of the enrollment period were replaced, and in anticipation of the loss of cows from the trial, one additional cow was enrolled into each treatment group at the end of the enrollment period. The final data set included 41 cows from which 11 were in the common source, low Mg group (CS-LM); 11 were in the common source, high Mg group (CS-HM); 10 were in 
the MIN-AD, low Mg group (MA-LM); and 9 were in the MIN-AD, high Mg group (MA-HM).

\section{Feeding Management, Feed Sampling, and Analysis}

Cows were housed in tiestalls and fed once daily between approximately 0700 and $0900 \mathrm{~h}$ for lactating cows and 0900 and $1030 \mathrm{~h}$ for dry cows. Individual feed intake was measured on a daily basis throughout the experiment by weighing feed delivered and refused. Cows were fed for a targeted refusal rate of $10 \%$ to allow for ad libitum intake. Rations were formulated using the Cornell Net Carbohydrate and Protein System (CNCPS, version 6.5, Cornell University, Ithaca, NY). Ingredient composition and analyzed diet composition of all prepartum and postpartum treatment diets are presented in Tables 1 and 2. All rations were composed of a base TMR containing forages and a base grain mix, which were common to all diets within the prepartum and postpartum periods, as well as a small inclusion rate grain mix. The small inclusion rate grain mixes were unique to each treatment group and contained the majority of supplemental minerals as well as ingredients to offset the higher inclusion rate of MA compared with CS. The base TMR was mixed in one batch for all prepartum cows and in one batch for all postpartum cows. Prior to delivery to the cow, smaller batches were made that included the small inclusion rate grain mixes.

Samples of TMR and all feed ingredients were collected weekly for determination of DM (dried at $40^{\circ} \mathrm{C}$ for $96 \mathrm{~h}$ in a forced-air oven). Weekly DM values were used to adjust as-fed inclusion rates of all forages and grain ingredients. At the end of the experiment, dried samples were ground to $2 \mathrm{~mm}$ in a Wiley mill

Table 1. Ingredient composition of prepartum and postpartum diets

\begin{tabular}{|c|c|c|c|c|c|c|}
\hline Ingredient (\% of DM) & \multicolumn{2}{|c|}{ Prepartum diet ${ }^{1}$} & \multicolumn{4}{|c|}{ Postpartum diet ${ }^{1}$} \\
\hline Wheat straw & 23.23 & 23.23 & 6.21 & 6.21 & 6.21 & 6.21 \\
\hline Ground shelled corn & 2.29 & 2.29 & 17.10 & 17.10 & 17.10 & 17.10 \\
\hline Wheat middlings & 6.54 & 6.54 & 4.71 & 4.71 & 4.71 & 4.71 \\
\hline Canola meal & 3.33 & 3.33 & 3.80 & 3.80 & 3.80 & 3.80 \\
\hline Corn gluten feed & 1.67 & 1.67 & 2.37 & 2.37 & 2.37 & 2.37 \\
\hline Distillers grains, ethanol & 1.10 & 0.62 & 1.29 & 1.02 & 1.13 & 0.58 \\
\hline Amino Plus ${ }^{2}$ & 2.32 & 2.32 & 5.70 & 5.70 & 5.70 & 5.70 \\
\hline Gemini Protein ${ }^{3}$ & 1.99 & 1.99 & 2.28 & 2.28 & 2.28 & 2.28 \\
\hline Energy Booster $100^{4}$ & - & - & 1.14 & 1.14 & 1.14 & 1.14 \\
\hline Biochlor $^{5}$ & 5.56 & 5.56 & - & - & - & - \\
\hline Mg oxide & 0.41 & 0.09 & 0.13 & 0.38 & 0.05 & 0.08 \\
\hline $\mathrm{MIN}-\mathrm{AD}^{7}$ & - & 1.78 & - & - & 0.52 & 1.66 \\
\hline Mineral oil & 0.02 & 0.02 & 0.02 & 0.02 & 0.02 & 0.02 \\
\hline Rumensin $^{8}$ & 0.04 & 0.04 & 0.06 & 0.06 & 0.06 & 0.06 \\
\hline Mineral and vitamin $\operatorname{mix}^{9}$ & 0.21 & 0.21 & 0.04 & 0.04 & 0.04 & 0.04 \\
\hline
\end{tabular}

\footnotetext{
${ }^{1}$ Treatments consisted of a $2 \times 2$ factorial arrangement of source assignments $(\mathrm{CS}=$ common sources of supplemental Ca and $\mathrm{Mg}$, or $\mathrm{MA}=$ supplemental minerals from a commercial source) beginning at $21 \mathrm{~d}$ before due date, and level assignments (LM = postpartum formulated diet $\mathrm{Mg}$ at $0.30 \%$ of $\mathrm{DM}$, or $\mathrm{HM}=$ postpartum formulated diet $\mathrm{Mg}$ at $0.45 \%$ of $\mathrm{DM}$ ) beginning within $1 \mathrm{~d}$ after parturition. Both the source and level assignments were continued through the 42-d postpartum study period.

${ }^{2}$ Heat-treated soybean meal, Ag Processing Inc., Omaha, NE.

${ }^{3}$ Protein blend, Papillon Agricultural Company Inc., Easton, MD.

${ }^{4}$ Commercial fat source, Milk Specialties Global, Eden Prairie, MN.

${ }^{5}$ Anionic supplement, Church \& Dwight Co. Inc., Trenton, NJ.

${ }^{6}$ 2-Hydroxy-4-(methylthio)-butanoic acid, Novus International, Saint Charles, MO.

${ }^{7} \mathrm{Ca}-\mathrm{Mg}$ dolomite; Papillon Agricultural Company, Easton, MD.

${ }^{8}$ Premix contained 26,400 g/t of monensin, Elanco Animal Health, Greenfield, IN.

${ }^{9}$ Prepartum mix contained $21,164 \mathrm{mg} / \mathrm{kg}$ of $\mathrm{Zn}, 5,580 \mathrm{mg} / \mathrm{kg}$ of Cu, 16,931 mg/kg of Mn, $147 \mathrm{mg} / \mathrm{kg}$ of Se, $144 \mathrm{mg} / \mathrm{kg}$ of Co, $611 \mathrm{mg} / \mathrm{kg}$ of I, $2,407 \mathrm{kIU} / \mathrm{kg}$ of vitamin $\mathrm{D}$, and $87,571 \mathrm{IU} / \mathrm{kg}$ of vitamin E; postpartum mix contained 103,050 mg/kg of Zn, 22,009 mg/kg of Cu, 82,440 mg/ $\mathrm{kg}$ of Mn, $693 \mathrm{mg} / \mathrm{kg}$ of Se, $712 \mathrm{mg} / \mathrm{kg}$ of Co, 3,012 mg/kg of I, 11,869 KIU $/ \mathrm{kg}$ of vitamin D, and 241,913 IU $/ \mathrm{kg}$ of vitamin E.
} 
and composited at 4-wk intervals for TMR samples and over the duration of the trial for all forages and grains. Composited samples were sent to a commercial laboratory (Cumberland Valley Analytical Services, Hagerstown, MD) for wet chemistry analysis of DM at $135^{\circ} \mathrm{C}$ (method 930.15, AOAC International, 2000), CP (method 990.03, AOAC International, 2000), ADF (method 973.18, AOAC International, 2000), NDF (Van Soest et al., 1991), starch (Hall, 2009), sugar (Dubois et al., 1956), ether extract (method 2003.05, AOAC International, 2006), minerals (method 985.01, AOAC International, 2000), chloride (silver nitrate titration after extraction with $0.5 \%$ nitric acid using a Brinkman Metrohm 848 Titrino Plus, Brinkmann Instruments Inc., Westbury, NY), and sulfur (according to Leco Organic Application Note "Sulfur and Carbon in Plant, Feed, Grain and Flower" Form 203-821-321, 5/08-REV1; Leco Corporation, St. Joseph, MI, https://www.leco.
com/support/library?submissionGuid=af10d5e1-77c1472b-8907-0140d9232810). Values for $\mathrm{NE}_{\mathrm{L}}$ of $\mathrm{TMR}$ composite samples were calculated according to NRC (2001). For calculation of daily DMI, weekly DM determinations from fresh TMR samples were further corrected for residual moisture in composite samples.

\section{Individual Animal Sampling, Analytical Methods, and Calculations}

Cows were observed daily throughout the experiment for health disorders by farm personnel. Body weights were measured weekly and BCS assigned by 2 scorers weekly according to Edmonson et al. (1989) beginning during the week before assignment to treatment and continuing through $42 \mathrm{~d}$ postpartum. Body condition scores were averaged over 2 scorers before statistical analysis.

Table 2. Analyzed nutrient composition (mean \pm SD) and partitioning of mineral intake by sources

\begin{tabular}{|c|c|c|c|c|c|c|}
\hline \multirow[b]{2}{*}{ Item } & \multicolumn{2}{|c|}{ Prepartum diet ${ }^{1}$} & \multicolumn{4}{|c|}{ Postpartum diet ${ }^{1}$} \\
\hline & $\mathrm{CS}$ & MA & CS-LM & CS-HM & MA-LM & MA-HM \\
\hline \multicolumn{7}{|l|}{ Nutrient $^{2}($ mean \pm SD $)$} \\
\hline $\mathrm{DM}(\%)$ & $43.0 \pm 1.8$ & $43.8 \pm 1.4$ & $43.0 \pm 1.0$ & $43.2 \pm 1.1$ & $42.8 \pm 1.0$ & $43.1 \pm 1.0$ \\
\hline $\mathrm{CP}(\%$ of DM) & $14.3 \pm 0.4$ & $14.1 \pm 0.6$ & $14.9 \pm 0.2$ & $15.0 \pm 0.3$ & $15.2 \pm 0.4$ & $15.4 \pm 0.4$ \\
\hline $\mathrm{ADF}(\%$ of DM) & $28.1 \pm 0.9$ & $29.5 \pm 0.6$ & $20.9 \pm 0.2$ & $21.5 \pm 0.6$ & $21.2 \pm 1.0$ & $21.1 \pm 0.5$ \\
\hline NDF (\% of DM) & $43.4 \pm 0.8$ & $45.4 \pm 0.9$ & $32.5 \pm 0.2$ & $32.9 \pm 0.3$ & $33.2 \pm 0.9$ & $33.4 \pm 0.9$ \\
\hline Lignin (\% of DM) & $3.9 \pm 0.2$ & $4.1 \pm 0.2$ & $3.3 \pm 0.1$ & $3.3 \pm 0.1$ & $3.2 \pm 0.1$ & $3.1 \pm 0.1$ \\
\hline Starch (\% of DM) & $15.8 \pm 0.8$ & $14.5 \pm 1.5$ & $25.5 \pm 0.9$ & $25.3 \pm 0.6$ & $24.6 \pm 0.4$ & $25.2 \pm 0.4$ \\
\hline $\mathrm{NFC}(\%$ of DM) & $33.0 \pm 1.2$ & $31.2 \pm 0.9$ & $45.2 \pm 0.7$ & $43.7 \pm 0.29$ & $43.5 \pm 1.3$ & $43.6 \pm 1.2$ \\
\hline Fat (\% of DM) & $2.17 \pm 0.08$ & $2.22 \pm 0.15$ & $3.25 \pm 0.26$ & $3.10 \pm 0.09$ & $3.04 \pm 0.13$ & $2.87 \pm 0.24$ \\
\hline $\mathrm{Ca}(\%$ of $\mathrm{DM})$ & $1.44 \pm 0.00$ & $1.40 \pm 0.00$ & $1.21 \pm 0.08$ & $1.13 \pm 0.06$ & $1.17 \pm 0.07$ & $1.24 \pm 0.03$ \\
\hline $\mathrm{P}(\%$ of $\mathrm{DM})$ & $0.35 \pm 0.00$ & $0.34 \pm 0.00$ & $0.36 \pm 0.01$ & $0.34 \pm 0.01$ & $0.37 \pm 0.01$ & $0.36 \pm 0.00$ \\
\hline $\mathrm{Mg}(\%$ of $\mathrm{DM})$ & $0.49 \pm 0.02$ & $0.52 \pm 0.01$ & $0.35 \pm 0.02$ & $0.40 \pm 0.01$ & $0.35 \pm 0.01$ & $0.48 \pm 0.00$ \\
\hline $\mathrm{K}(\%$ of $\mathrm{DM})$ & $1.08 \pm 0.02$ & $1.08 \pm 0.03$ & $1.00 \pm 0.03$ & $0.98 \pm 0.03$ & $1.02 \pm 0.03$ & $1.01 \pm 0.04$ \\
\hline $\mathrm{S}(\%$ of $\mathrm{DM})$ & $0.45 \pm 0.01$ & $0.44 \pm 0.01$ & $0.32 \pm 0.01$ & $0.33 \pm 0.02$ & $0.33 \pm 0.02$ & $0.33 \pm 0.02$ \\
\hline $\mathrm{Na}(\%$ of $\mathrm{DM})$ & $0.26 \pm 0.01$ & $0.25 \pm 0.02$ & $0.42 \pm 0.01$ & $0.42 \pm 0.00$ & $0.43 \pm 0.01$ & $0.43 \pm 0.01$ \\
\hline $\mathrm{Cl}(\%$ of $\mathrm{DM})$ & $0.79 \pm 0.04$ & $0.80 \pm 0.05$ & $0.53 \pm 0.01$ & $0.53 \pm 0.02$ & $0.54 \pm 0.01$ & $0.53 \pm 0.02$ \\
\hline DCAD (mEq/100 g of DM) & $-11.2 \pm 1.0$ & $-11.1 \pm 1.4$ & $8.7 \pm 1.1$ & $7.7 \pm 1.2$ & $8.9 \pm 1.7$ & $9.2 \pm 1.9$ \\
\hline $\mathrm{NE}_{\mathrm{L}}(\mathrm{Mcal} / \mathrm{kg})$ & $1.46 \pm 0.02$ & $1.42 \pm 0.01$ & $1.64 \pm 0.01$ & $1.61 \pm 0.01$ & $1.62 \pm 0.01$ & $1.60 \pm 0.01$ \\
\hline $\mathrm{MP}^{3}(\mathrm{~g} / \mathrm{kg}$ of $\mathrm{DM})$ & 90.5 & 90.2 & 113.0 & 113.0 & 112.7 & 112.5 \\
\hline MP intake $(\mathrm{g} / \mathrm{d})$ & 1,439 & 1,515 & 2,158 & 2,237 & 2,141 & 2,284 \\
\hline \multicolumn{7}{|l|}{ Mineral intake source ${ }^{4}$} \\
\hline $\mathrm{Mg}$ from MIN-AD (\% of Mg) & - & 39.3 & - & - & 17.1 & 39.8 \\
\hline $\mathrm{Mg}$ from $\mathrm{MgO}(\%$ of $\mathrm{Mg}$ ) & 45.4 & 9.2 & 20.6 & 51.9 & 7.1 & 9.3 \\
\hline $\mathrm{Mg}$ from other (\% of $\mathrm{Mg}$ ) & 54.7 & 51.5 & 79.4 & 48.1 & 75.8 & 51.0 \\
\hline Ca from MIN-AD ( $\%$ of $\mathrm{Ca})$ & - & 27.3 & - & - & 9.6 & 28.8 \\
\hline Ca from limestone ( $\%$ of $\mathrm{Ca}$ ) & 65.0 & 40.4 & 42.4 & 46.6 & 35.1 & 14.5 \\
\hline Ca from other ( $\%$ of $\mathrm{Ca}$ ) & 35.0 & 32.4 & 57.6 & 53.4 & 55.4 & 56.7 \\
\hline
\end{tabular}

${ }^{1}$ Treatments consisted of a $2 \times 2$ factorial arrangement of source assignments $(\mathrm{CS}=$ common sources of supplemental Ca and Mg, or MA $=$ supplemental minerals from a commercial source) beginning at $21 \mathrm{~d}$ before due date, and level assignments (LM = postpartum formulated diet $\mathrm{Mg}$ at $0.30 \%$ of $\mathrm{DM}$, or $\mathrm{HM}=$ postpartum formulated diet $\mathrm{Mg}$ at $0.45 \%$ of $\mathrm{DM}$ ) beginning within $1 \mathrm{~d}$ after parturition. Both the source and level assignments were continued through the 42-d postpartum study period.

${ }^{2}$ Weekly samples were composited over 4 -wk intervals, chemical analysis conducted on 2 composites for each prepartum diet, and 4 composites for each postpartum diet.

${ }^{3}$ Metabolizable protein intake as predicted by the Cornell Net Carbohydrate and Protein System (version 6.5, Cornell University, Ithaca, NY) based on analyzed composition of forages.

${ }^{4}$ Based on actual 21-d intake prepartum and postpartum, predicted diet MP concentration, formulated supplemental mineral source inclusion rates, and analyzed ration composite mineral concentrations; $\mathrm{Mg}$ and Ca from "other" represent basal ingredients and were determined by difference. MIN-AD is a commercial Ca-Mg dolomite (MIN-AD Inc., Winnemucca, NV). 
After calving, all cows were milked 3 times daily at 0600, 1400, and 2200 h. Daily milk weights were recorded and daily milk yield calculated as the sum of yields at all 3 milkings through the $42-d$ study period. Milk samples were collected at 3 consecutive milkings each week, mixed with a bronopol preservative, and stored at $4^{\circ} \mathrm{C}$ until transportation to a commercial laboratory (DairyOne, Ithaca, NY) within $72 \mathrm{~h}$ of collection for analysis of milk fat, protein, lactose, TS, and MUN using mid-infrared techniques (method 972.16, AOAC International, 2006), and SCC was determined using optical fluorescence (method 978.26, AOAC International, 2006). Somatic cell scores were calculated from SCC $\left[\right.$ SCS $=\log _{2}(\mathrm{SCC} / 100,000)+3$; Shook, 1993]. Milk yield at the corresponding milking was used to weight milk composition and calculate yield of fat, protein, lactose, and TS. Weekly average yield of $3.5 \%$ FCM was calculated $[3.5 \% \mathrm{FCM}=(0.432 \times \mathrm{kg}$ of average weekly milk yield $)+(16.216 \times \mathrm{kg}$ of fat $)$; Gaines, 1928; Erdman, 2011] as well as weekly average yield of $\mathrm{ECM}[\mathrm{ECM}=(0.327 \times \mathrm{kg}$ average weekly milk yield $)$ $+(12.95 \times \mathrm{kg}$ of fat $)+(7.65 \times \mathrm{kg}$ of true protein $)$; Tyrrell and Reid, 1965]. Milk production efficiency was calculated from weekly average DMI and ECM (efficiency $=\mathrm{kg}$ of $\mathrm{ECM} / \mathrm{kg}$ of DMI).

Blood samples were collected via coccygeal venipuncture between 0600 and $0730 \mathrm{~h}$ twice weekly (Monday and Friday) from $\mathrm{d}-28$ relative to expected parturition until parturition, within $2 \mathrm{~h}$ of parturition (d 0 ), daily from d 1 through 7 in milk, and 3 times per week (Monday, Wednesday, and Friday) thereafter through 21 DIM. Samples were collected using 10-mL sodium heparin evacuated tubes (158 USP, Becton Dickinson and Company, Franklin Lakes, NJ) and 20 G vacutainer needles (Becton Dickinson and Company) and placed on ice immediately after collection. Plasma was harvested after centrifugation at 2,000 $\times g$ for $20 \mathrm{~min}$ at $4^{\circ} \mathrm{C}$, aliquoted into 1.7-mL microfuge tubes, snap frozen in liquid nitrogen, and stored at $-20^{\circ} \mathrm{C}$ until analysis. A subset of samples were analyzed for BHB and nonesterified fatty acids (NEFA). A commercial kit (Catachem Inc., Oxford, CT) was adapted for analysis of plasma BHB concentrations in a 96-well plate. Briefly, $5 \mu \mathrm{L}$ of standards, controls, and unknowns were pipetted in triplicate. Readings $(340 \mathrm{~nm})$ were taken after addition of $150 \mu \mathrm{L}$ of the sample diluent reagent and after $2 \mathrm{~min}$ of incubation $\left(37^{\circ} \mathrm{C}\right)$ after the addition of $30 \mu \mathrm{L}$ of the catalyst reagent. The difference between readings was compared with the standard curve to determine BHB concentration. Analysis of plasma NEFA concentrations were conducted in triplicate using a commercial enzymatic kit [HR Series NEFA HR (2), Wako Pure Chemical Industries, Osaka, Japan]. Spectrophoto- metric measurements were conducted using a tunable microplate reader (SpectraMax 190, Molecular Devices, Sunnyvale, CA). Coefficients of variation (both interand intraassay) for all assays were maintained below 10\%. A different subset of samples was analyzed for mineral concentrations at the Cornell Animal Health and Diagnostic Center (Ithaca, NY) on an automated analyzer (Hitachi Modular P800, Roche Diagnostics, Indianapolis, IN).

Weekly calculations of prepartum and postpartum energy balance (EBAL) were determined according to NRC (2001) equations for the following: energy intake $($ Mcal $/ \mathrm{d})=$ weekly DMI average $(\mathrm{kg} / \mathrm{d}) \times \operatorname{diet} \mathrm{NE}_{\mathrm{L}}$ (Mcal $/ \mathrm{kg}$ of DM); maintenance requirement $(\mathrm{Mcal})=$ week metabolic BW $\left(\mathrm{kg}^{0.75}\right) \times 0.08\left(\mathrm{Mcal} / \mathrm{kg}^{0.75}\right.$ per d) ; pregnancy requirement $(\mathrm{Mcal})=(0.00318 \times \mathrm{d}$ of gestation -0.0352$) \times(1 / 0.218)$; and lactation requirement $(\mathrm{Mcal} / \mathrm{d})=$ wk average milk yield $(\mathrm{kg} / \mathrm{d}) \times[(0.0929 \times$ fat percentage $)+(0.0563 \times$ true protein percentage $)$ $+(0.0395 \times$ lactose percentage $)]$. Weekly values for EBAL were determined as follows:

prepartum $\mathrm{NE}_{\mathrm{L}}(\mathrm{Mcal} / \mathrm{d})$ balance = energy intake

(Mcal of $\mathrm{NE}_{\mathrm{L}} / \mathrm{d}$ ) - [maintenance requirement

(Mcal of $\left.\mathrm{NE}_{\mathrm{L}} / \mathrm{d}\right)+$ pregnancy requirement

(Mcal of $\left.\mathrm{NE}_{\mathrm{L}} / \mathrm{d}\right)$ ], and

postpartum $\mathrm{NE}_{\mathrm{L}}(\mathrm{Mcal} / \mathrm{d})$ balance = energy intake

(Mcal of $\mathrm{NE}_{\mathrm{L}} / \mathrm{d}$ ) - [maintenance requirement

(Mcal of $\left.\mathrm{NE}_{\mathrm{L}} / \mathrm{d}\right)+$ lactation requirement

$$
\text { (Mcal of } \left.\mathrm{NE}_{\mathrm{L}} / \mathrm{d}\right) \text { ]. }
$$

\section{Statistical Analysis}

Prepartum data were restricted to the 3 wk before actual parturition for each cow. Daily DMI and milk production were reduced to weekly means before statistical analysis. To account for the prepartum twice weekly and postpartum 3 times weekly blood sampling schedule, average day of sampling relative to actual parturition is reported. Prepartum and postpartum data were analyzed separately and plasma measurements from d 0 were included in prepartum analysis because samples were taken before commencing postpartum treatment assignments. Postpartum plasma minerals were analyzed separately for effects between $\mathrm{d} 1$ to 7 and between d 9 to 21 to determine effects that may have been manifested in the days immediately following parturition and because of differences in sampling intensity. All statistical analyses were conducted with the 
statistical software SAS (version 9.4, SAS Institute Inc., Cary, NC). The distribution of parity group by source, level, and overall treatment group was assessed using a chi-squared test using the FREQ procedure. Differences in previous lactation 305-d mature-equivalent milk production and covariate BW and BCS were tested by ANOVA using the MIXED procedure, and the model included effects of source, level, and the interaction of source and level. Continuous outcomes were subjected to ANOVA using the MIXED procedure. Continuous measures not repeated over time were analyzed for the fixed effects of source, level (postpartum only), parity group (second vs. third lactation), and the interaction between source and level (postpartum only). All measurements repeated over time were subjected to repeated measures ANOVA using the REPEATED statement in the MIXED procedure of SAS (Littell et al., 1996). The fixed effects of time, source, level (postpartum only), parity group (second vs. third lactation), and the 2- and 3-way interactions of source, level (postpartum only), and time were included in the model. Cow within source (prepartum) or source and level (postpartum) was the random effect. When available, covariate measurements collected in the week before treatment assignment were included in all models. Previous lactation 305-d mature-equivalent milk production was included as a covariate for milk yield. The KenwardRogers method was used for estimation of denominator degrees of freedom. Four covariance structures were tested for each model and the model with the lowest Akaike's information criterion was selected (Littell et al., 1996). For data on all plasma measurements, the following covariance structures were tested: compound symmetry, heterogeneous compound symmetry, antedependence 1, and unstructured. For all other data, the following covariance structures were tested: compound symmetry, heterogeneous compound symmetry, au- toregressive order 1 , and heterogeneous autoregressive order 1 . When $P \leq 0.15$ for interactions with time, the SLICE option was used in the LSMEANS statement to conduct an $F$-test to determine at which levels of time the treatment groups differed. Plots of studentized residuals were visually inspected for normality and homogeneity of variance. When nonnormality of residual variance was evident (NEFA and postpartum BHB), data were log-transformed and analysis repeated. Least squares means and SE, or geometric mean and 95\% CI (NEFA and postpartum BHB), are reported throughout. Significance was declared at $P \leq 0.05$ and trends are discussed at $0.05<P \leq 0.15$.

\section{RESULTS}

\section{Study Population and Experimental Diets}

Data from one cow fed CS-HM were removed from 21 DIM to the end of the observation period due to clinical mastitis that caused a severe drop in milk production. Data from a cow fed MA-HM were removed past 33 DIM due to an injury that required her to be removed from treatment diet and moved to a bedded pack. All data for these 2 cows before illness or injury remained in the data set. The description of the final study population after exclusion of cows that calved early or calved with twins, including distribution of parity and means of previous lactation 305-d mature-equivalent milk production, days on treatment, and BW and BCS at enrollment, is presented in Table 3. No differences were present in any of these parameters with the exception of a trend for a source by level interaction in covariate BCS; however, differences were relatively small.

Analyzed dietary $\mathrm{Mg}$ concentration of postpartum treatment diets were different from formulated (Table 2 ). Both of the LM diets had analyzed Mg concentra-

Table 3. Distribution of lactation number and means \pm SD for previous lactation 305-d mature equivalent (MEq) milk production, days on prepartum treatment diets, BW, and BCS at enrollment for treatment groups

\begin{tabular}{|c|c|c|c|c|c|c|c|}
\hline Variable & \multicolumn{4}{|c|}{ Treatment $^{1}$} & \multicolumn{3}{|c|}{$P$-value ${ }^{2}$} \\
\hline 2nd & 7 & 7 & 6 & 4 & 0.54 & 0.76 & 0.84 \\
\hline $3 \mathrm{rd}+$ & 4 & 4 & 4 & 5 & & & \\
\hline Previous 305-d MEq (kg) & $15,753 \pm 1,819$ & $15,959 \pm 2,042$ & $15,650 \pm 2,109$ & $15,327 \pm 1,208$ & 0.53 & 0.92 & 0.65 \\
\hline Days on treatment & $22 \pm 6$ & $21 \pm 4$ & $21 \pm 6$ & $21 \pm 6$ & 0.81 & 0.94 & 0.59 \\
\hline
\end{tabular}

${ }^{1}$ Treatments consisted of a $2 \times 2$ factorial arrangement of source assignments $(\mathrm{CS}=$ common sources of supplemental $\mathrm{Ca}$ and $\mathrm{Mg}$, or $\mathrm{MA}=$ supplemental minerals from a commercial source) beginning at $21 \mathrm{~d}$ before due date, and level assignments (LM = postpartum formulated diet $\mathrm{Mg}$ at $0.30 \%$ of $\mathrm{DM}$, or $\mathrm{HM}=$ postpartum formulated diet $\mathrm{Mg}$ at $0.45 \%$ of $\mathrm{DM}$ ) beginning within $1 \mathrm{~d}$ after parturition. Both the source and level assignments were continued through the 42 -d postpartum study period.

${ }^{2} \mathrm{~S}=$ source; $\mathrm{L}=$ level. 
Table 4. Least squares means and SE for prepartum DMI, DMI as a percentage of BW, energy balance (EBAL), BW, BW change, and BCS for cows fed 1 of 2 sources of supplemental dietary $\mathrm{Ca}$ and $\mathrm{Mg}$

\begin{tabular}{|c|c|c|c|c|c|}
\hline \multirow[b]{2}{*}{ Variable $^{1}$} & \multicolumn{2}{|c|}{ Treatment $^{2}$} & \multirow[b]{2}{*}{ SEM } & \multicolumn{2}{|c|}{$P$-value ${ }^{3}$} \\
\hline & CS & MA & & $\mathrm{S}$ & $\mathrm{S} \times \mathrm{W}$ \\
\hline DMI (kg/d) & 15.9 & 16.8 & 0.3 & 0.03 & 0.52 \\
\hline DMI (\% of BW) & 2.00 & 2.10 & 0.03 & 0.02 & 0.88 \\
\hline EBAL (Mcal/d) & 7.2 & 8.1 & 0.4 & 0.12 & 0.71 \\
\hline BW $(\mathrm{kg})$ & 800 & 801 & 3 & 0.70 & 0.19 \\
\hline BW change ${ }^{4}(\mathrm{~kg})$ & 20 & 22 & 3 & 0.58 & - \\
\hline BCS & 3.42 & 3.47 & 0.02 & 0.13 & 0.56 \\
\hline \multicolumn{6}{|c|}{${ }^{1}$ Data collected in the $3 \mathrm{wk}$ before parturition. } \\
\hline \multicolumn{6}{|c|}{$\begin{array}{l}{ }^{2} \text { Treatments consisted of a } 2 \times 2 \text { factorial arrangement of source assignments }(\mathrm{CS}=\text { common sources of supple- } \\
\text { mental Ca and } \mathrm{Mg} \text {, or } \mathrm{MA}=\text { supplemental minerals from a commercial source) beginning at } 21 \mathrm{~d} \text { before due } \\
\text { date, and level assignments }(\mathrm{LM}=\text { postpartum formulated diet } \mathrm{Mg} \text { at } 0.30 \% \text { of } \mathrm{DM} \text {, or } \mathrm{HM}=\text { postpartum } \\
\text { formulated diet } \mathrm{Mg} \text { at } 0.45 \% \text { of } \mathrm{DM}) \text { beginning within } 1 \mathrm{~d} \text { after parturition. Both the source and level assign- } \\
\text { ments were continued through the } 42 \text {-d postpartum study period. } \\
{ }^{3} \mathrm{~S}=\text { source; } \mathrm{W}=\text { week. }\end{array}$} \\
\hline
\end{tabular}

tions of $0.35 \%$ of DM, above the targeted $0.30 \%$ of DM. The concentration of $\mathrm{Mg}$ in the HM diets was different from the formulated $0.45 \%$ of DM with the CS-HM diet at $0.40 \%$ of DM and the MA-HM diet at $0.48 \%$ of DM. When analyzed composition of forage composites and formulated grain mix compositions were inputted into CNCPS, calculated Mg composition of the prepartum rations was 0.45 and $0.50 \%$ of $\mathrm{DM}$ for CS and MA, respectively. For postpartum rations, calculated $\mathrm{Mg}$ composition was $0.33,0.46,0.33$, and $0.47 \%$ of $\mathrm{DM}$ for CS-LM, CS-HM, MA-LM, and MA-HM, respectively. Variation in ingredient inclusion rate as well as cumulative inherent error in TMR sampling, processing, and laboratory analysis could have contributed to those differences in composite composition. Using the analyzed TMR composite $\mathrm{Mg}$ concentrations and formulated inclusion rates of supplemental mineral sources, the percentage of $\mathrm{Mg}$ and $\mathrm{Ca}$ from supplemental sources was calculated and the percentage from the basal ingredients was calculated by the difference. These estimations are presented in Table 2. Overall, differences in dietary $\mathrm{Mg}$ concentrations were apparent between LM and HM groups, justifying analysis of data for any effects of level.

\section{Effects of Prepartum Source of Ca and Mg on Prepartum Outcomes}

$D M I, E B A L, B W$, and BCS. Prepartum DMI, EBAL, BW, BW change, and BCS are presented in Table 4. Prepartum DMI was higher for cows fed MA $(\mathrm{CS}=15.9$ vs. $\mathrm{MA}=16.8 \mathrm{~kg} / \mathrm{d}, P=0.03$; Figure $1)$. Dry matter intake as a percentage of $\mathrm{BW}$ was also higher in cows fed MA (CS $=2.00$ vs. $\mathrm{MA}=2.10 \%$ of BW, $P=0.02)$. Calculated prepartum EBAL was similarly affected by supplemental mineral source and EBAL tended to be higher for cows fed MA (CS = 7.2 vs. $\mathrm{MA}=8.1 \mathrm{Mcal} / \mathrm{d}, P=0.12)$. Prepartum BCS tended to be higher for cows fed MA (CS $=3.42$ vs. $\mathrm{MA}=3.47, P=0.13$ ); however, absolute differences were small. No differences were detected for prepartum BW or BW change.

Plasma NEFA, BHB, and Mineral Concentrations. Prepartum plasma NEFA and BHB concentrations are presented in Table 5, and prepartum plasma mineral concentrations are presented in Table 6. Plasma concentrations of NEFA prepartum were lower in cows fed MA [geometric mean (back-transformed 95\% CI); $\mathrm{CS}=142(130-155)$ vs. $\mathrm{MA}=117(107-129) \mu \mathrm{Eq} / \mathrm{L}$; $P=0.005]$. No differences were detected for prepartum plasma concentrations of $\mathrm{BHB}, \mathrm{Ca}$, or $\mathrm{Mg}$. Cows fed MA had higher concentrations of $\mathrm{P}$ in plasma prepartum $(\mathrm{CS}=1.69$ vs. $\mathrm{MA}=1.79 \mathrm{mmol} / \mathrm{L} ; P=0.02)$ and there tended to be an interaction of source and day where the difference in plasma $\mathrm{P}$ was larger for samples collected closer to calving $(P=0.10)$.

\section{Effects of Source and Level on Postpartum Outcomes}

DMI, EBAL, BW, and BCS. Postpartum DMI, EBAL, BW, BW change, and BCS are presented in Table 7. An interaction of source, level, and time was observed for postpartum DMI $(P=0.03$; Figure 1$)$ such that DMI was numerically higher for cows fed MA-HM in wk 2 postpartum and for cows fed CS-HM in wk 4. Although different patterns were apparent over time for different treatment groups, tests of treatment effects at individual weeks were not significant. A tendency was observed for a source, level, and time interaction for 


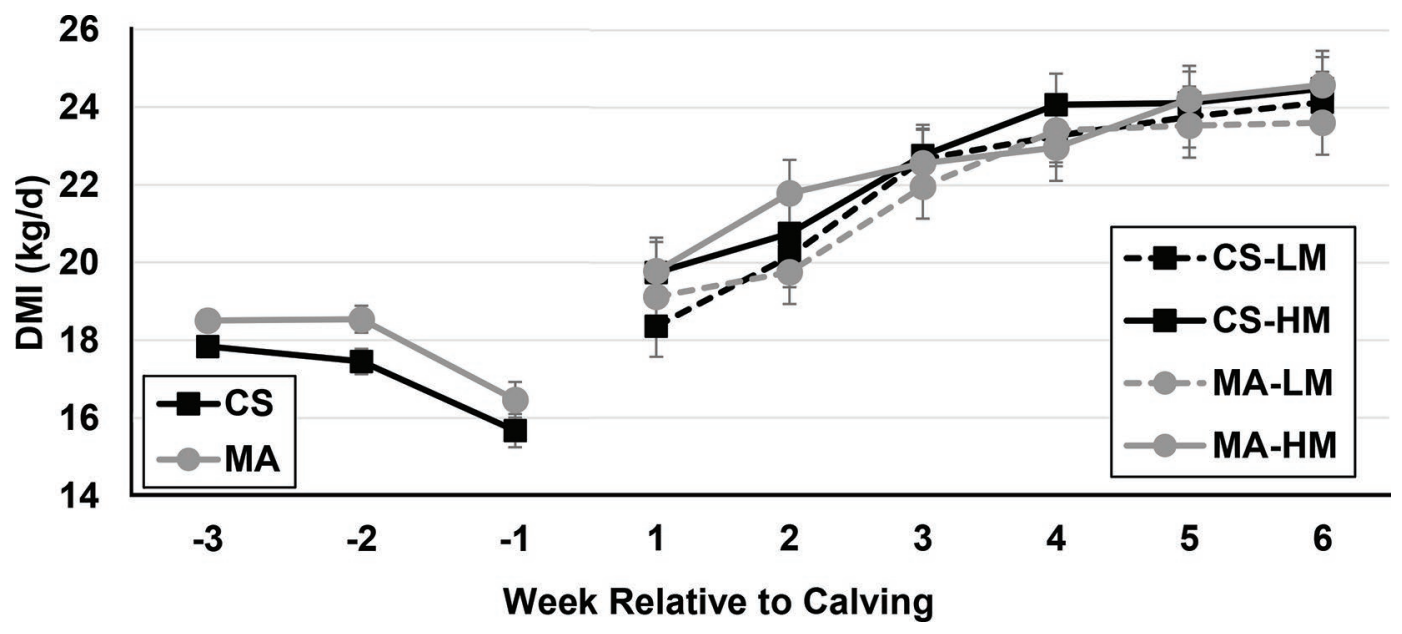

Figure 1. Least squares means and SE for DMI $(\mathrm{kg} / \mathrm{d})$ for 3 wk prepartum and 6 wk postpartum. Treatments consisted of a $2 \times 2$ factorial arrangement of source assignments $(\mathrm{CS}=$ common sources of supplemental $\mathrm{Ca}$ and $\mathrm{Mg}$, or $\mathrm{MA}=$ supplemental minerals from a commercial source) beginning at $21 \mathrm{~d}$ before the due date, and level assignments ( $\mathrm{LM}=$ postpartum formulated diet $\mathrm{Mg}$ at $0.30 \%$ of $\mathrm{DM}$, or $\mathrm{HM}=$ postpartum formulated diet $\mathrm{Mg}$ at $0.45 \%$ of $\mathrm{DM}$ ) beginning within $1 \mathrm{~d}$ after parturition. Prepartum and postpartum data were analyzed separately. An effect of source was detected for prepartum DMI $(P=0.03)$ with no source by week effect $(P=0.52)$. A 3 -way interaction of source, level, and week was detected for postpartum DMI $(P=0.03)$.

DMI as a percentage of $\mathrm{BW}(P=0.14)$. A tendency was observed for an effect of source on BW change such that cows fed MA lost less BW between wk 1 and 6 postpartum $(\mathrm{CS}=-61$ vs. $\mathrm{MA}=-43 \mathrm{~kg}, P=0.11$ ). Body condition score tended to be higher for cows fed MA than cows fed $\mathrm{CS}(\mathrm{CS}=3.14$ vs. $\mathrm{MA}=3.20, P=$ 0.14 ); differences were small but were consistent with effects on BW change and plasma NEFA concentrations. No differences in calculated EBAL or average BW were detected postpartum.

Milk Yield and Composition. Results for milk yield, milk composition, and milk production efficiency are presented in Table 7. Differences were not detected by source or level for milk yield or content and yield of true protein, lactose, or TS. Similarly, no differences in milk production efficiency or SCS were observed. A source by week effect was found for fat content ( $P$ $=0.07)$, fat yield $(P=0.02), 3.5 \%$ fat-corrected yield $(P=0.04)$, TS yield $(P=0.05)$, and energy-corrected yield $(P=0.03)$. These effects were driven primarily by higher content and yield of fat in wk 1 for cows fed MA $(P<0.05$; Figure 2). The DIM at which the first milk sampling occurred did tend to differ by source; however, it was closer to parturition by approximately $1 \mathrm{~d}$ for cows fed CS compared with cows fed MA ( $P=$ 0.09 ; $\mathrm{CS}=3.25 \pm 0.42$ vs. $\mathrm{MA}=4.34 \pm 0.46$ ). Controlling for the random effect of DIM at sampling within sample week did not alter interpretation of the data and therefore the effect was not included in the final model. A level by week effect was observed on milk fat content $(P=0.01$; Figure 2$)$ such that milk fat content was similar in all weeks except wk 5 when cows fed LM had lower milk fat content $(P=0.03)$. Although this effect was statistically significant, the effect in wk 5 likely has minimal biological importance. A trend for a level by week effect was also found for MUN concentration $(P=0.01)$, and groups differed only in wk $1(P=0.01)$ and cows fed LM had higher MUN.

Plasma NEFA, BHB, and Mineral Concentrations. Results for postpartum plasma NEFA and BHB are presented in Table 5 . Cows fed MA tended to have lower NEFA during the postpartum period [CS $=604$ $(528-690)$ vs. $\mathrm{MA}=512(445-590) \mu \mathrm{Eq} / \mathrm{L} ; P=0.09]$. A trend was observed for an interaction of source and level on postpartum plasma BHB concentrations [CS$\mathrm{LM}=7.9$ (6.7-9.2), CS-HM $=6.9(5.9-8.1)$, MA-LM $=6.3(5.3-7.3)$, and MA-HM $=7.3(6.2-8.6) \mathrm{mg} / \mathrm{dL}$; $P=0.09] ;$ BHB concentrations were numerically lowest in cows fed MA-LM, but multiple comparisons using Tukey's adjustment did not detect differences between specific groups.

Results for postpartum plasma mineral concentrations are presented in Table 6 and were analyzed separately as d 1 to 7 and $\mathrm{d} 9$ to 21 . Plasma $\mathrm{Mg}$ from d 1 to 7 tended to be lower for cows fed LM postpartum $(\mathrm{LM}=0.82$ vs. $\mathrm{HM}=0.85 \mathrm{mmol} / \mathrm{L}, P=0.11)$ and plasma $\mathrm{Mg}$ also tended to be lower for cows fed MA ( $\mathrm{CS}=0.85$ vs. $\mathrm{MA}=0.82 \mathrm{mmol} / \mathrm{L}, P=0.10)$. From d 9 to 21 , similar trends for source and level were found for plasma $\mathrm{Mg}$ concentrations and plasma $\mathrm{Mg}$ tended to be lower for cows fed LM ( $\mathrm{LM}=0.89$ vs. HM $=$ $0.93 \mathrm{mmol} / \mathrm{L}, P=0.07)$ and for cows fed MA $(\mathrm{CS}=$ 0.93 vs. $\mathrm{MA}=0.89 \mathrm{mmol} / \mathrm{L}, P=0.14)$. Postpartum plasma $\mathrm{P}$ from $\mathrm{d} 1$ to 7 tended to be higher for cows 


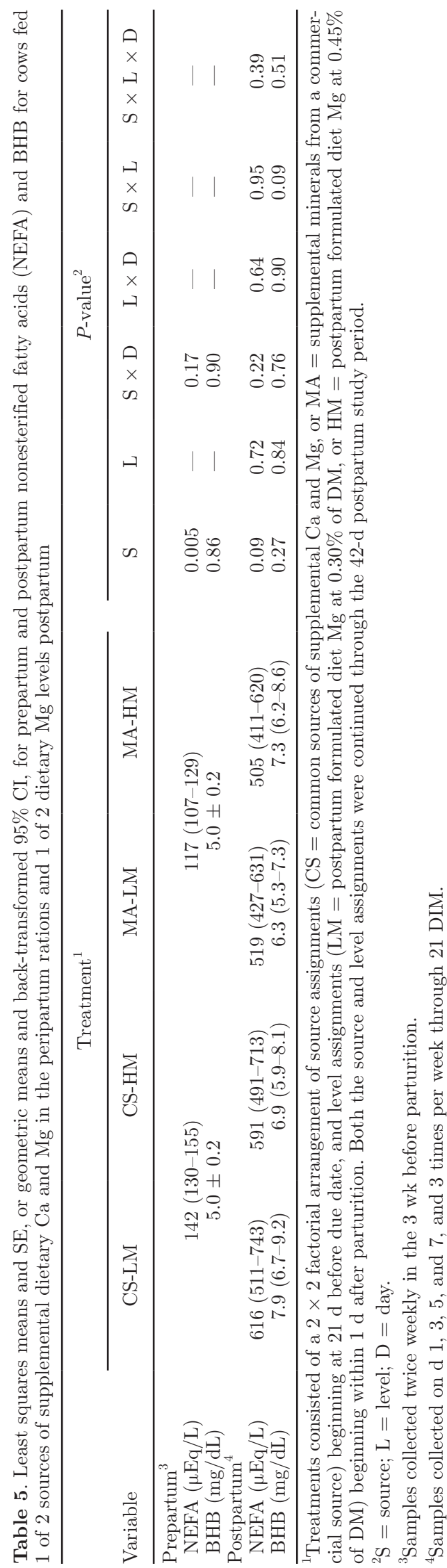

fed MA $(\mathrm{CS}=1.40$ vs. $\mathrm{MA}=1.51 \mathrm{mmol} / \mathrm{L}, P=0.09)$. No effect was observed of source on plasma $\mathrm{P}$ from $\mathrm{d}$ 9 to 21, but cows fed LM tended to have lower plasma $\mathrm{P}$ in that period $(\mathrm{LM}=1.65 \mathrm{vs} . \mathrm{HM}=1.74 \mathrm{mmol} / \mathrm{L}$, $P=0.13)$. No differences were detected for plasma Ca concentrations in either period.

Hypocalcemia Prevalence and Health Disorders. Incidence of hypocalcemia was low in this trial. Peak prevalence of hypocalcemia occurred at 1 DIM and $54 \%$ of cows had plasma Ca concentrations $\leq 2.125 \mathrm{mmol} / \mathrm{L}$ (Martinez et al., 2016) with only $26 \%$ of cows having plasma $\mathrm{Ca} \leq 2.0 \mathrm{mmol} / \mathrm{L}$ (Reinhardt et al., 2011). By 3 DIM, prevalence of plasma $\mathrm{Ca} \leq 2.125$ $\mathrm{mmol} / \mathrm{L}$ was $7 \%$ and prevalence of plasma $\mathrm{Ca} \leq 2.0$ $\mathrm{mmol} / \mathrm{L}$ was $5 \%$. Incidence of health disorders were as follows: retained placenta (MA-LM, $\mathrm{n}=1$ ), metritis (CS-LM, $\mathrm{n}=3$; CS-HM, $\mathrm{n}=1$; MA-LM, $\mathrm{n}=2$; MA$\mathrm{HM}, \mathrm{n}=1$ ), mastitis (CS-HM, $\mathrm{n}=1$; MA-HM, $\mathrm{n}=1$ ), displaced abomasum (CS-LM, $\mathrm{n}=1$ ), hyperketonemia (defined by urine ketones "moderate" or higher for 2 consecutive days within 10 DIM, or severe decreases in intake and milk production $>10$ DIM; CS-LM, $\mathrm{n}=2$; MA-LM, $\mathrm{n}=1$; MA-HM, $\mathrm{n}=3$ ). The sample size was insufficient to test the difference in incidence of health disorders between treatment groups.

\section{DISCUSSION}

\section{Mineral Status}

The primary objective of this experiment was to determine the effect of varying the primary supplemental source of $\mathrm{Ca}$ and $\mathrm{Mg}$ in the peripartum rations, and postpartum feeding rate of $\mathrm{Mg}$, on plasma mineral status during the transition period. Based on the small numerical differences observed for several outcomes in the study, the statistical power to detect these differences is low. Especially for the interaction between source and level, the probability of type II error is high and the results should be interpreted in that context. The trend for a difference in postpartum plasma $\mathrm{Mg}$ concentration indicated an effect of both dietary concentration of $\mathrm{Mg}$ and source of supplemental minerals. Increasing dietary $\mathrm{Mg}$ concentration increased blood concentrations of $\mathrm{Mg}$ for ruminants in some studies (Chicco et al., 1972; Greene et al., 1983a) but not others (Van Ravenswaay et al., 1989; Jittakhot et al., 2004). Urine Mg excretion more consistently responds to the increased $\mathrm{Mg}$ supply (Chicco et al., 1972; Van Ravenswaay et al., 1989; Jittakhot et al., 2004). This response indicates more total absorbed $\mathrm{Mg}$ and is consistent with an increase in absorption of $\mathrm{Mg}$ as ruminal supply of Mg increase (Care et al., 1984; Weiss, 2004). Contrary to our hypotheses, minimal effects of dietary 
Table 6. Least squares means and SE for prepartum and postpartum plasma mineral concentrations for cows fed 1 of 2 sources of supplemental dietary $\mathrm{Ca}$ and $\mathrm{Mg}$ in the peripartum rations and 1 of 2 dietary $\mathrm{Mg}$ levels postpartum

\begin{tabular}{|c|c|c|c|c|c|c|c|c|c|c|c|}
\hline \multirow[b]{2}{*}{ Variable } & \multicolumn{4}{|c|}{ Treatment $^{1}$} & \multirow[b]{2}{*}{ SEM } & \multicolumn{6}{|c|}{$P$-value ${ }^{2}$} \\
\hline & CS-LM & CS-HM & MA-LM & MA-HM & & S & $\mathrm{L}$ & $\mathrm{S} \times \mathrm{D}$ & $\mathrm{L} \times \mathrm{D}$ & $\mathrm{S} \times \mathrm{L}$ & $\mathrm{S} \times \mathrm{L} \times \mathrm{D}$ \\
\hline \multicolumn{12}{|l|}{ Prepartum $^{3}$} \\
\hline $\mathrm{Ca}(\mathrm{mmol} / \mathrm{L})$ & \multicolumn{2}{|c|}{2.44} & \multicolumn{2}{|c|}{2.44} & 0.02 & 0.85 & - & 0.93 & - & - & - \\
\hline $\mathrm{Mg}(\mathrm{mmol} / \mathrm{L})$ & \multicolumn{2}{|c|}{0.96} & \multicolumn{2}{|c|}{0.96} & 0.01 & 0.59 & - & 0.33 & - & - & - \\
\hline $\mathrm{P}(\mathrm{mmol} / \mathrm{L})$ & \multicolumn{2}{|c|}{1.69} & \multicolumn{2}{|c|}{1.79} & 0.03 & 0.02 & - & 0.10 & - & - & - \\
\hline \multicolumn{12}{|c|}{ Postpartum (d 1-7) } \\
\hline $\mathrm{P}(\mathrm{mmol} / \mathrm{L})$ & 1.43 & 1.38 & 1.47 & 1.55 & 0.07 & 0.09 & 0.86 & 0.82 & 0.63 & 0.32 & 0.49 \\
\hline \multicolumn{12}{|c|}{ Postpartum (d 9-21) } \\
\hline $\mathrm{Ca}(\mathrm{mmol} / \mathrm{L})$ & 2.56 & 2.63 & 2.56 & 2.58 & 0.03 & 0.44 & 0.17 & 0.19 & 0.38 & 0.40 & 0.82 \\
\hline $\mathrm{Mg}(\mathrm{mmol} / \mathrm{L})$ & 0.91 & 0.94 & 0.87 & 0.92 & 0.02 & 0.14 & 0.07 & 0.83 & 0.34 & 0.64 & 0.18 \\
\hline $\mathrm{P}(\mathrm{mmol} / \mathrm{L})$ & 1.67 & 1.70 & 1.63 & 1.79 & 0.06 & 0.68 & 0.13 & 0.84 & 0.91 & 0.30 & 0.69 \\
\hline
\end{tabular}

${ }^{1}$ Treatments consisted of a $2 \times 2$ factorial arrangement of source assignments $(\mathrm{CS}=$ common sources of supplemental $\mathrm{Ca}$ and $\mathrm{Mg}$, or $\mathrm{MA}=$ supplemental minerals from a commercial source) beginning at $21 \mathrm{~d}$ before due date, and level assignments (LM = postpartum formulated diet $\mathrm{Mg}$ at $0.30 \%$ of $\mathrm{DM}$, or $\mathrm{HM}=$ postpartum formulated diet $\mathrm{Mg}$ at $0.45 \%$ of $\mathrm{DM}$ ) beginning within $1 \mathrm{~d}$ after parturition. Both the source and level assignments were continued through the 42 -d postpartum study period.

${ }^{2} \mathrm{~S}=$ source; $\mathrm{L}=$ level; $\mathrm{D}=$ day.

${ }^{3}$ Samples collected twice per week in the 3 wk before parturition and within $2 \mathrm{~h}$ after parturition.

${ }^{4}$ Samples collected daily from 1 through 7 DIM.

${ }^{5}$ Samples collected 3 times per week from 8 through 21 DIM.

Table 7. Least squares means and SE for DMI, energy balance (EBAL), BW, and BCS parameters as well as milk yield and composition over the first 6 wk postpartum for cows fed 1 of 2 sources of supplemental dietary Ca and Mg in the peripartum rations and 1 of 2 dietary Mg levels postpartum

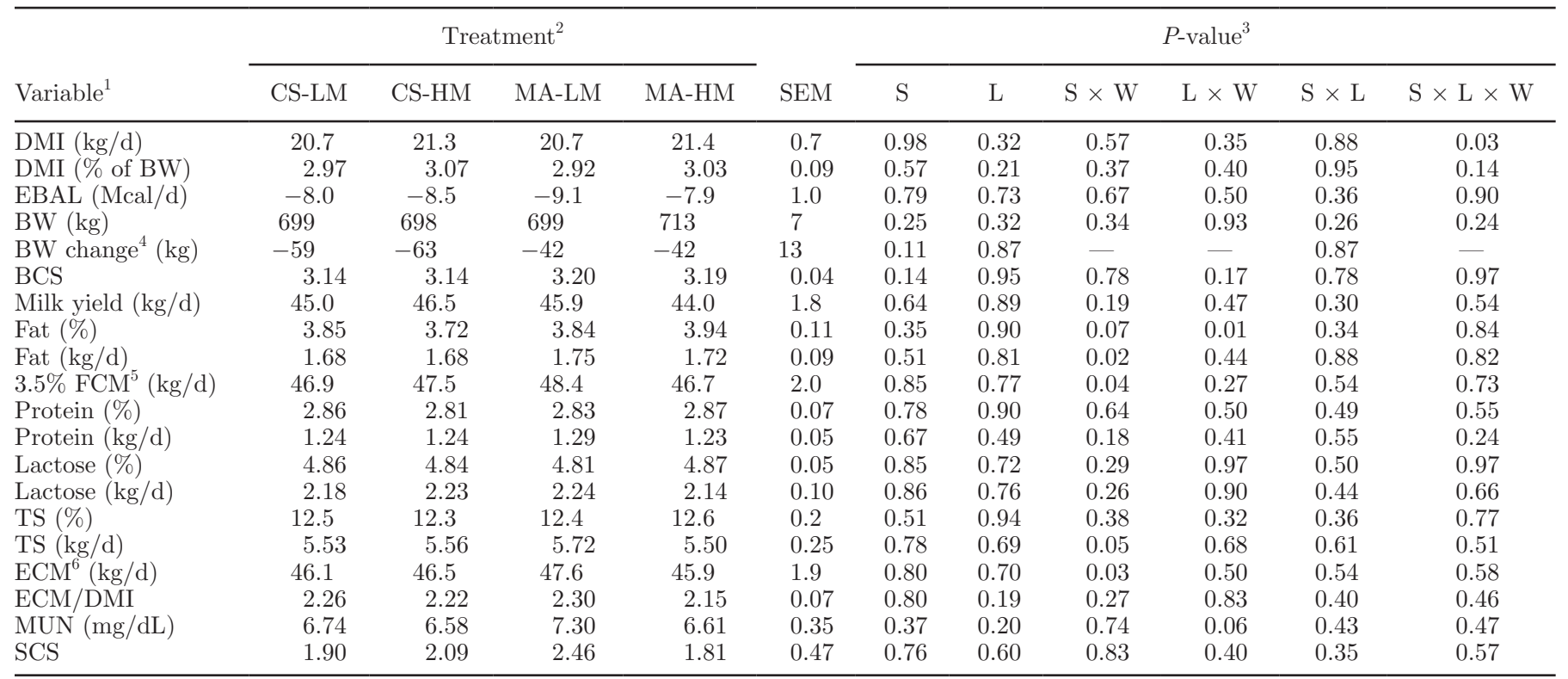

${ }^{1}$ Data collected weekly or daily and reduced to weekly means (DMI and milk yield), from parturition through 6 wk postpartum.

${ }^{2}$ Treatments consisted of a $2 \times 2$ factorial arrangement of source assignments $(\mathrm{CS}=$ common sources of supplemental Ca and $\mathrm{Mg}$, or $\mathrm{MA}=$ supplemental minerals from a commercial source) beginning at $21 \mathrm{~d}$ before due date, and level assignments (LM = postpartum formulated diet $\mathrm{Mg}$ at $0.30 \%$ of $\mathrm{DM}$, or $\mathrm{HM}=$ postpartum formulated diet $\mathrm{Mg}$ at $0.45 \%$ of $\mathrm{DM}$ ) beginning within $1 \mathrm{~d}$ after parturition. Both the source and level assignments were continued through the 42-d postpartum study period.

${ }^{3} \mathrm{~S}=$ source; $\mathrm{L}=$ level; $\mathrm{W}=$ week.

${ }^{4}$ Difference between BW measurement at wk 1 and 6 .

${ }^{5} 3.5 \% \mathrm{FCM}=(0.432 \times \mathrm{kg}$ of wk average milk yield $)+(16.216 \times \mathrm{kg}$ of fat $)$.

${ }^{6} \mathrm{ECM}=(0.327 \times \mathrm{kg}$ of wk average milk yield $)+(12.95 \times \mathrm{kg}$ of fat $)+(7.65 \times \mathrm{kg}$ of true protein $)$. 
A

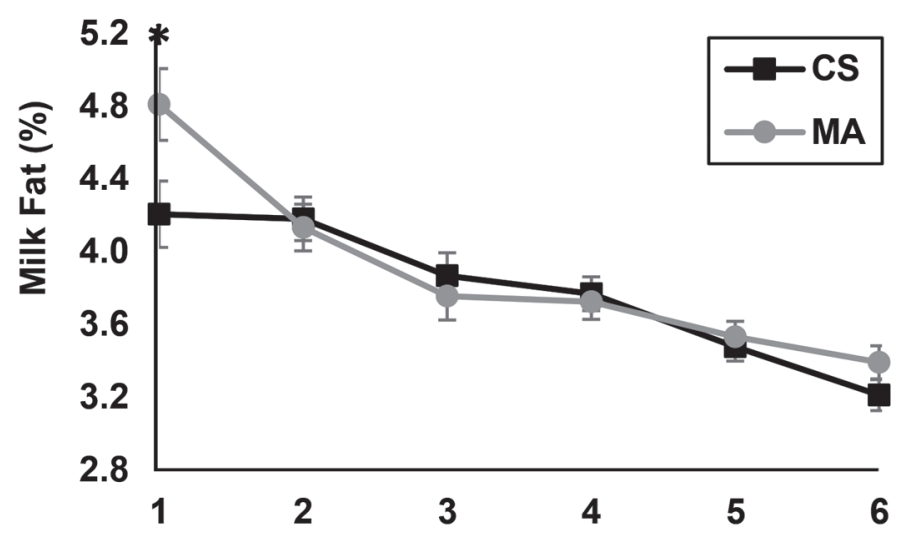

C

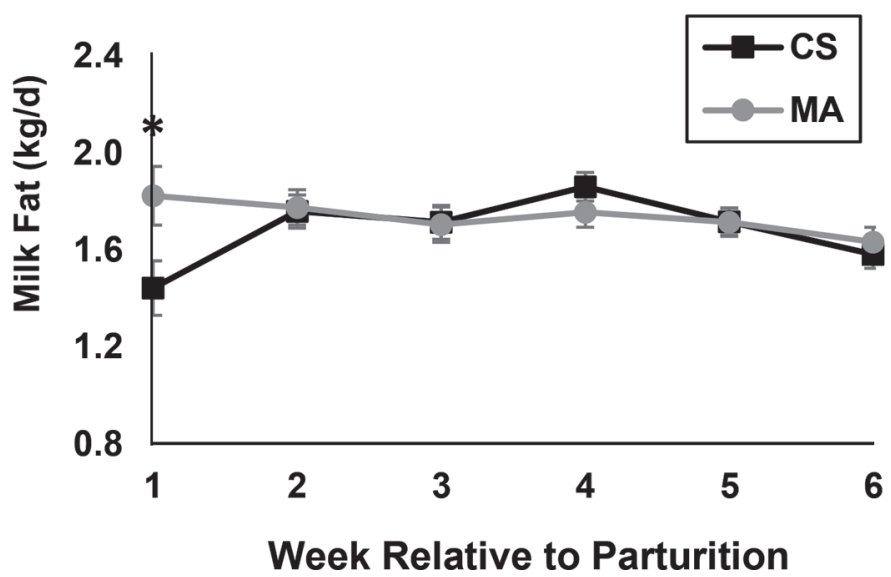

B
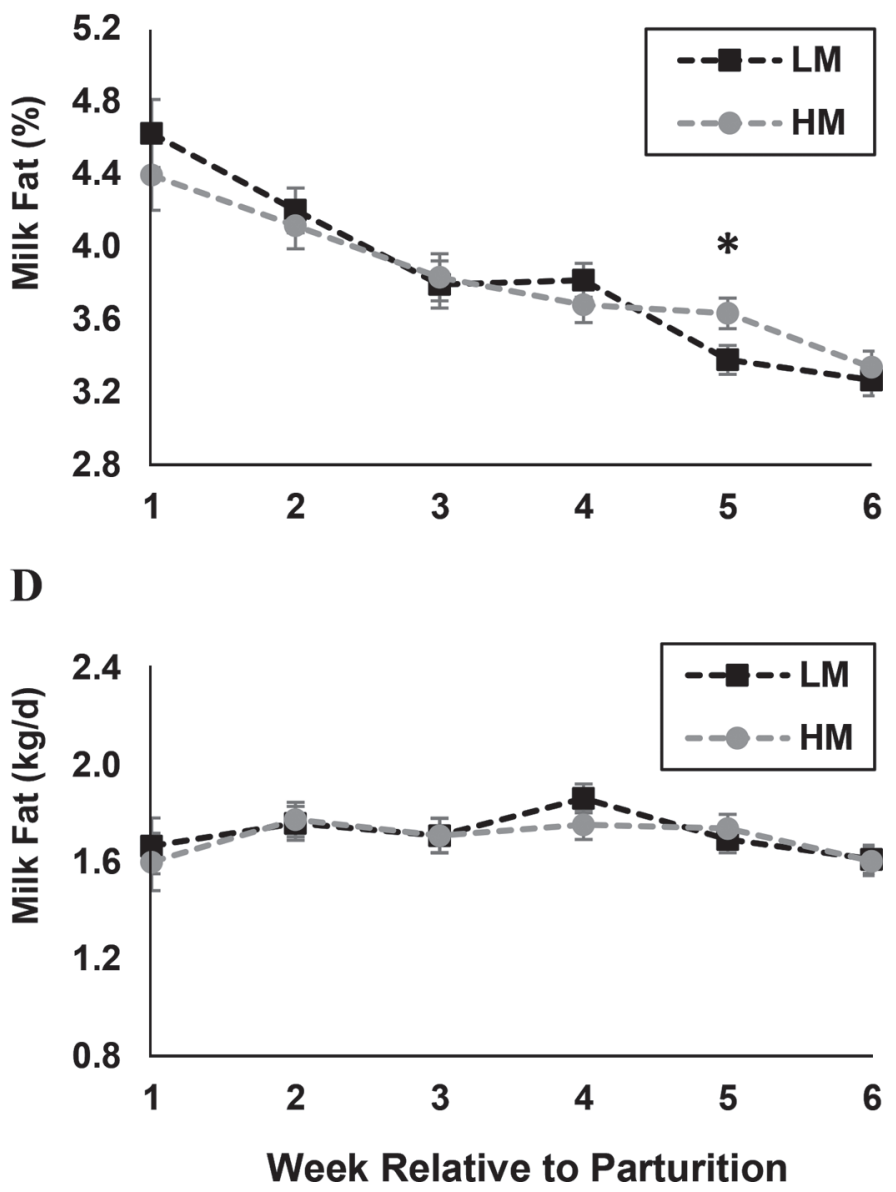

Figure 2. Least squares means and SE for milk fat content by supplemental mineral source (A), milk fat content by postpartum dietary $\mathrm{Mg}$ level (B), milk fat yield by supplemental mineral source (C), and milk fat yield by postpartum dietary Mg level (D). Treatments consisted of a $2 \times 2$ factorial arrangement of source assignments $(\mathrm{CS}=$ common sources of supplemental $\mathrm{Ca}$ and $\mathrm{Mg}$, or $\mathrm{MA}=$ supplemental minerals from a commercial source) beginning at $21 \mathrm{~d}$ before due date, and level assignments (LM = postpartum formulated diet $\mathrm{Mg}$ at $0.30 \%$ of $\mathrm{DM}$, or $\mathrm{HM}=$ postpartum formulated diet $\mathrm{Mg}$ at $0.45 \%$ of $\mathrm{DM}$ ) beginning within $1 \mathrm{~d}$ after parturition. There were no interactions of source and level; therefore, results are presented as main effects. A source by week interaction was observed for milk fat content $(P=0.07)$ and milk fat yield $(P=0.02)$ and a level by week interaction was observed for milk fat content $(P=0.01)$, but there was no effect of level or interaction of level and time on milk fat yield $(P>0.44)$. For outcomes with treatment by time interactions, asterisks $\left(^{*}\right)$ indicate time points at which treatment means significantly differ $(P \leq 0.05)$.

$\mathrm{Mg}$ level on other aspects of plasma mineral status were found, indicating that the small differences in plasma $\mathrm{Mg}$ did not affect $\mathrm{Ca}$ homeostasis. Marginal effects of dietary $\mathrm{Mg}$ level on other outcomes measured in this experiment indicated that the differences in plasma $\mathrm{Mg}$ concentrations observed in cows fed LM did not limit intake or performance compared with cows fed HM. Formulated $\mathrm{Mg}$ concentrations of all rations were above NRC (2001) requirements, and the analysis of TMR composite samples showed that the LM rations had higher $\mathrm{Mg}$ concentrations than formulated. Increasing ration $\mathrm{K}$ concentration has been shown to inhibit $\mathrm{Mg}$ absorption in ruminants (Care et al., 1984; Jittakhot et al., 2004; Weiss, 2004) and dietary K concentration in this study was quite low. Taken together, it is plausible that all diets allowed for total absorbed Mg above requirements in both the LM rations as well as the HM rations, and therefore physiological functions requiring $\mathrm{Mg}$ were supplied adequately despite differences in plasma Mg concentrations.

A trend for a difference in postpartum plasma $\mathrm{Mg}$ concentrations was also observed for cows fed MA compared with cows fed CS where cows fed MA had lower plasma $\mathrm{Mg}$ concentrations. One potential mechanism for this difference in blood $\mathrm{Mg}$ is greater bioavailability of $\mathrm{Mg}$ from $\mathrm{Mg}$ oxide as opposed to $\mathrm{Mg}$ from the commercial $\mathrm{Ca}-\mathrm{Mg}$ dolomite. Early work in steers comparing $\mathrm{Mg}$ oxide to dolomitic limestone suggested that the latter had reduced bioavailability of $\mathrm{Mg}$ (Moore et al., 1971) or Mg and Ca (Gerken and Fontenot, 1967). Sim- 
ilar results have been observed in sheep fed $\mathrm{Mg}$ oxide or dolomitic limestone (Rahnema and Fontenot, 1983). In contrast, Crawford et al. (2008) observed no difference in apparent absorption of $\mathrm{Ca}, \mathrm{Mg}$, or $\mathrm{P}$ for cows fed a $\mathrm{Ca}-\mathrm{Mg}$ dolomite in partial replacement of $\mathrm{Mg}$ oxide and limestone. The discrepancy between studies may be a result of the solubility of the $\mathrm{Ca}$ and $\mathrm{Mg}$ in the particular mineral sources used. A large amount of variation in apparent absorption of $\mathrm{Mg}$ from different $\mathrm{Mg}$ oxide sources has been identified in the literature (Ammerman et al., 1972; Van Ravenswaay et al., 1989; Xin et al., 1989). These differences are potentially due to the calcination temperature used in manufacturing and the resulting solubility of $\mathrm{Mg}$ (Van Ravenswaay et al., 1989) as well as physical processing of these mineral sources and the resulting particle size (Jesse et al., 1981). It is plausible that the same variability exists for $\mathrm{Ca}-\mathrm{Mg}$ dolomites, although to the authors' knowledge this variation has not been described in ruminant feed sources.

No differences were detected in prepartum plasma $\mathrm{Mg}$ in the current study. This may have been due to the high mineral feeding rates and high DMI observed in that period, offsetting potential differences in bioavailability with higher total supply. Because demand for $\mathrm{Mg}$ is relatively low in the dry period for fetal development (House and Bell, 1993) compared with during lactation when milk production causes a drain on circulating Mg (Shappell et al., 1987; Tsioulpas et al., 2007), concentrations of $\mathrm{Mg}$ in blood are likely more easily maintained in the prepartum period. Differences in bioavailability of $\mathrm{Mg}$ in this period would likely have been more sensitively reflected in the urine (Jesse et al., 1981; Van Ravenswaay et al., 1989). Plasma Mg concentrations do not always increase in response to feeding mineral sources with apparently higher $\mathrm{Mg}$ bioavailability (Xin et al., 1989); however, strong linear correlations between apparently absorbed $\mathrm{Mg}$ and urinary $\mathrm{Mg}$ as well as urinary $\mathrm{Mg}$ and plasma $\mathrm{Mg}$ in sheep (Chicco et al., 1972) indicate that these measures provide insight into the $\mathrm{Mg}$ absorbed from the diet in some situations. Because bioavailability was not measured in this trial, this cannot be definitively identified as the cause of differences in plasma $\mathrm{Mg}$ concentrations.

Interactions between ruminal concentrations of $\mathrm{Ca}$ and $\mathrm{Mg}$ and subsequent absorption have been investigated in sheep, demonstrating decreased absorption of $\mathrm{Mg}$ as ruminal $\mathrm{Ca}$ concentrations increase (Behar, 1975; Care et al., 1984). Whereas the site of Ca absorption in ruminants is primarily thought to be postruminal (Yano et al., 1979; Greene et al., 1983c; Rahnema and Fontenot, 1983), evidence suggests that significant ruminal absorption of $\mathrm{Ca}$ can occur in some situations (Greene et al., 1983b; Khorasani et al., 1997) and this could contribute to the antagonistic relationship between absorption of these 2 divalent cations. In a trial conducted in transition dairy cows, Kronqvist et al. (2011) fed 1 of 3 levels of Ca prepartum and found that as prepartum dietary Ca was increased, apparent $\mathrm{Mg}$ digestibility and postpartum plasma $\mathrm{Mg}$ concentrations were decreased. In that study, dietary Ca concentration was only varied prepartum and did not affect blood Ca concentrations, but differences in plasma $\mathrm{Mg}$ concentrations were evident in the postpartum period, suggesting a carryover effect of prepartum dietary Ca level. In the current study, despite the fact that prepartum dietary concentrations of $\mathrm{Ca}$ were similar, ruminal supply of Ca may have been higher in cows fed MA due to higher intakes or greater solubility of $\mathrm{Ca}$ from the $\mathrm{Ca}-\mathrm{Mg}$ dolomite. This may have impaired $\mathrm{Mg}$ absorption, resulting in compromised postpartum plasma $\mathrm{Mg}$ concentrations in those cows. The lack of a detected difference in plasma Ca concentrations due to a supplemental mineral source may indicate that the difference in postpartum plasma $\mathrm{Mg}$ concentrations did not impair Ca homeostasis.

Higher plasma $\mathrm{P}$ concentrations for cows fed MA were observed both prepartum and in the week after parturition. Blood P concentrations have been demonstrated to increase when higher dietary $\mathrm{P}$ concentrations are fed (Barton et al., 1987; Peterson et al., 2005), and if the same response can be expected when total intake of $\mathrm{P}$ is increased, the higher intake observed in cows fed MA prepartum may have contributed to this difference. In a study conducted in steers in which feeding a dolomitic form of $\mathrm{Mg}$ was compared with feeding $\mathrm{Mg}$ oxide and $\mathrm{Mg}$ carbonate, apparent $\mathrm{P}$ absorption tended to increase for steers fed the dolomite (Moore et al., 1971). Baseline blood P concentration was lower in steers fed the dolomite in that study, so it is unclear if this is an effect of source. A possible antagonistic effect of $\mathrm{Ca}$ or $\mathrm{Mg}$, depending on the amount and solubility of these minerals in different parts of the gastrointestinal tract, may have been responsible for altering solubility of $\mathrm{P}$. This has been demonstrated in ruminant diets with increasing Ca concentrations (Yano et al., 1979) and potentially could lead to decreased absorption of $\mathrm{P}$ due to the formation of chelates.

\section{DMI and Performance}

Despite detecting minimal effects on plasma mineral concentrations in this study, we found meaningful differences in intake and plasma energy metabolites for cows fed supplemental minerals from the commercial $\mathrm{Ca}-\mathrm{Mg}$ dolomite source compared with commonly used $\mathrm{Mg}$ oxide and limestone. This suggests that differences in performance were at least partly the result of some 
mechanism other than differences in mineral status in the transition period. Different $\mathrm{Mg}$ oxide and $\mathrm{Mg}$ carbonate sources have been demonstrated in vitro, using rumen fluid from dairy cows (Jesse et al., 1981; Schaefer et al., 1982), and in vivo, in dairy heifers, to have differences in buffering capacity (Schaefer et al., 1982). In addition to the effects observed on DMI, the differences in milk fat percentage and yield in wk 1 for cows fed MA suggest that the differences in ration mineral sources may have altered ruminal fermentation. Although buffering capacity was not measured in the current trial with these particular mineral sources, it is plausible that differences in buffering capacity between sources could influence rumen health during the transition period. The transition onto diets immediately after parturition with higher concentrations of rapidly fermentable carbohydrates has been demonstrated to result in subacute ruminal acidosis (Penner et al., 2007). Although variation in buffering capacity of the mineral sources and feeding rates may contribute to the differences observed in postpartum DMI, it is unlikely that this accounts for the increase in DMI observed prepartum.

A difference in the palatability of mineral sources in this study is a potential contributing factor to the effects observed on DMI. To the authors' knowledge, direct comparisons of $\mathrm{Mg}$ oxide, limestone, and $\mathrm{Ca}$ $\mathrm{Mg}$ dolomites fed to transition dairy cows with diets similar to those in the current study are not available for comparison. A similar approach in steers in which $\mathrm{Mg}$ oxide and limestone were partially replaced with $\mathrm{Ca}-\mathrm{Mg}$ dolomites determined that DMI of steers fed a high-concentrate diet were not affected by these mineral source differences (Crawford et al., 2008). In a review conducted by Erdman et al. (1980), several studies investigating the inclusion of $\mathrm{Mg}$ oxide as a buffer were compiled and feeding $\mathrm{Mg}$ oxide resulted in decreased DMI compared with controls (no buffer included in ration) when fed in conjunction with lowforage $(<30 \%)$ diets, whereas no effect was observed in high-forage diets. The rations in the current study all had $>50 \%$ forage (DM basis); however, different diet characteristics, such as the inclusion rate of the mineral sources, may influence effects on DMI. Feeding buffers in ruminant rations has been demonstrated to increase the liquid passage rate of rumen contents (Haaland and Tyrrell, 1982), and in steers fed Ca-Mg dolomites compared with $\mathrm{Mg}$ oxide and limestone, a decrease in the flow of fluid out of the rumen has been demonstrated (Crawford et al., 2008). Differences in liquid passage rate between source treatments in the current study may have resulted in altered ruminal fermentation. In addition, ruminal $\mathrm{Mg}$ supply has been identified as an important component of voluntary feed intake (Ammerman et al., 1971, 1972; Chicco et al., 1973) as well as cellulose digestion (Ammerman et al., 1971) in sheep, and decreased Mg supply resulted in decreased DMI as well as decreased in vivo and in vitro cellulose digestion. If the $\mathrm{Mg}$ oxide fed in the current study were more ruminally soluble, this may have resulted in unintended consequences for rumen fermentation, such as increased liquid passage rate and fluctuations in rumen $\mathrm{Mg}$ concentrations. In the high fiber prepartum rations fed in the current trial, differences in rumen fermentation efficiency due to lower liquid passage rates or a more consistent release of $\mathrm{Mg}$ in the rumen could have resulted in increased fiber digestion rates for cows fed MA and subsequently higher DMI. The speculated alterations in palatability, passage rate, and ruminal digestion cannot be confirmed from the current trial, but future work assessing mineral sources in transition cow rations should investigate these interactions.

Although effects of treatment on DMI in the postpartum period were not as consistent as in the prepartum period, other factors may have altered the response to these sources postpartum. First, prepartum ration composition and expected digestion and passage rates vary from the postpartum rations and probably influence the effect of the mineral sources on rumen functions. Second, inclusion rate of the $\mathrm{Ca}-\mathrm{Mg}$ dolomite in the postpartum ration as a percentage of DM was similar in the MA-HM group compared with the prepartum MA ration, but was much lower in the MA-LM group. Higher inclusion rates of the mineral source may be necessary to observe the effects seen in the prepartum period. Third, other diet factors aside from alterations in passage rate and $\mathrm{Mg}$ supply may have limited ruminal fermentation postpartum. Milk urea N concentrations are related to measures of ration $\mathrm{CP}$, intake, and productivity (Broderick and Clayton, 1997), and previous work has observed MUN concentrations similar to that observed in the current study in groups with limitations in performance (Olmos Colmenero and Broderick, 2006). Decreased MUN concentrations can be a reflection of feeding diets in which rumen degradable protein and rumen ammonia concentrations are limiting, which can result in decreased microbial growth and ultimately reduce milk and milk protein yield (Olmos Colmenero and Broderick, 2006). Low MUN concentrations in the current study suggest that there may have been limitations in microbial growth; however, diets were formulated for adequate MP supply and it is possible that performance was not compromised because protein requirements not met with microbial supply were met with rumen undegradable sources. 


\section{Energy Metabolites, BW, and BCS}

Plasma concentrations of NEFA were lower for cows fed MA during the prepartum period in this study, consistent with the higher DMI observed in those cows. Postpartum plasma NEFA concentrations tended to remain lower over the first 3 wk after parturition for cows fed MA despite the time and Mg feeding rate dependent effects on intake. Consistent with lower plasma NEFA concentrations, cows fed MA tended to maintain higher BCS and lose less BW in the postpartum period. When effects on energy metabolites are considered with the increase in milk fat percentage and yield in wk 1 for cows fed MA, the data suggest that the source of additional milk fat was not mobilized adipose tissue and further supports altered ruminal fermentation in cows fed MA.

\section{CONCLUSIONS}

Varying postpartum feeding rate of $\mathrm{Mg}$, as well as the primary source of supplemental $\mathrm{Ca}$ and $\mathrm{Mg}$, for periparturient multiparous cows resulted in altered plasma $\mathrm{Mg}$ and $\mathrm{P}$ concentrations. The consequences of these changes are unclear because performance was similar for all groups. Ultimately, these differences in plasma $\mathrm{Mg}$ concentrations did not affect plasma Ca status and suggest that any of the Mg level or mineral source approaches tested in this study could be implemented to maintain similar Ca status postpartum. The population of cows in this study had low incidence of hypocalcemia overall. Increases in DMI in the prepartum period, and in parts of the postpartum period, due to supplemental source of $\mathrm{Ca}$ and $\mathrm{Mg}$, as well as decreases in plasma NEFA concentrations, suggest that there may be an opportunity for strategic use of mineral sources in the transition period to promote intake and metabolic health.

\section{ACKNOWLEDGMENTS}

The authors gratefully acknowledge MIN-AD Inc. (Winnemucca, NV) and Papillon Agricultural Company Inc. (Easton, MD) for partial financial support of this project. We also thank the staff at the Cornell University Ruminant Center (Ithaca, NY) for care and management of the animals: Zane Leno for feeding management of the experimental diets, and Allison Lawton, Charlene Ryan, Shana Coffey, Claira Seely, and Danielle Harris for their assistance in sample collection and analysis.

\section{REFERENCES}

Ammerman, C. B., C. F. Chicco, P. E. Loggins, and L. R. Arrington. 1972. Availability of different inorganic salts of magnesium to sheep. J. Anim. Sci. 34:122-126.

Ammerman, C. B., C. F. Chicco, J. E. Moore, P. A. Van Walleghem, and L. R. Arrington. 1971. Effect of dietary magnesium on voluntary feed intake and rumen fermentations. J. Dairy Sci. 54:12881293.

AOAC International. 2000. Official Methods of Analysis. 18th ed. AOAC International, Arlington, VA.

AOAC International. 2006. Official Methods of Analysis. 18th ed. AOAC International, Arlington, VA.

Barton, B. A., N. A. Jorgensen, and H. F. DeLuca. 1987. Impact of prepartum dietary phosphorus intake on calcium homeostasis at parturition. J. Dairy Sci. 70:1186-1191.

Behar, J. 1975. Effect of calcium on magnesium absorption. Am. J. Physiol. 229:1590-1595.

Broderick, G. A., and M. K. Clayton. 1997. A statistical evaluation of animal and nutritional factors influencing concentrations of milk urea nitrogen. J. Dairy Sci. 80:2964-2971.

Caixeta, L. S., P. A. Ospina, M. B. Capel, and D. V. Nydam. 2015. The association of subclinical hypocalcemia, negative energy balance and disease with bodyweight change during the first 30 days post-partum in dairy cows milked with automatic milking systems. Vet. J. 204:150-156.

Care, A. D., R. C. Brown, A. R. Farrar, and D. W. Pickard. 1984. Magnesium absorption from the digestive tract of sheep. Q. J. Exp. Physiol. 69:577-587.

Chamberlin, W. G., J. R. Middleton, J. N. Spain, G. C. Johnson, M. R. Ellersieck, and P. Pithua. 2013. Subclinical hypocalcemia, plasma biochemical parameters, lipid metabolism, postpartum disease, and fertility in postparturient dairy cows. J. Dairy Sci. 96:7001-7013.

Chapinal, N., M. Carson, T. F. Duffield, M. Capel, S. Godden, M. Overton, J. E. Santos, and S. J. LeBlanc. 2011. The association of serum metabolites with clinical disease during the transition period. J. Dairy Sci. 94:4897-4903.

Chapinal, N., S. J. Leblanc, M. E. Carson, K. E. Leslie, S. Godden, M. Capel, J. E. Santos, M. W. Overton, and T. F. Duffield. 2012. Herd-level association of serum metabolites in the transition period with disease, milk production, and early lactation reproductive performance. J. Dairy Sci. 95:5676-5682.

Chicco, C. F., C. B. Ammerman, W. G. Hillis, and L. R. Arrington. 1972. Utilization of dietary magnesium by sheep. Am. J. Physiol. 222:1469-1472.

Chicco, C. F., C. B. Ammerman, and P. E. Loggins. 1973. Effect of age and dietary magnesium on voluntary feed intake and plasma magnesium in ruminants. J. Dairy Sci. 56:822-824.

Crawford, G. I., C. D. Keeler, J. J. Wagner, C. R. Krehbiel, G. E. Erickson, M. B. Crombie, and G. A. Nunnery. 2008. Effects of calcium magnesium carbonate and roughage level on feedlot performance, ruminal metabolism, and site and extent of digestion in steers fed high-grain diets. J. Anim. Sci. 86:2998-3013.

Dubois, M., K. A. Gilles, J. K. Hamilton, P. A. Rebers, and F. Smith. 1956. Colorimetric method for determination of sugars and related substances. Anal. Chem. 28:350-356.

Edmonson, A. J., I. J. Lean, L. D. Weaver, T. Farver, and G. Webster. 1989. A body condition scoring chart for Holstein dairy cows. J. Dairy Sci. 72:68-78.

Erdman, R. A. 2011. Monitoring feed efficiency in dairy cows using fat-corrected milk per unit dry matter intake. Pages 69-79 in Proc. Mid-Atlantic Nutrition Conference, University of Maryland, College Park. Mid-Atlantic Feed Industry Council, College Park, MD.

Erdman, R. A., R. L. Botts, R. W. Hemken, and L. S. Bull. 1980. Effect of dietary sodium bicarbonate and magnesium oxide on production and physiology in early lactation. J. Dairy Sci. 63:923-930.

Gaines, W. L. 1928. The energy basis of measuring milk yield in dairy cows. Ill. Agric. Exp. Sta. Bull. 308:403-436. 
Gerken, H. J. Jr., and J. P. Fontenot. 1967. Availability and utilization of magnesium from dolomitic limestone and magnesium oxide in steers. J. Anim. Sci. 26:1404-1408.

Green, H. B., R. L. Horst, D. C. Beitz, and E. T. Littledike. 1981. Vitamin D metabolites in plasma of cows fed a prepartum lowcalcium diet for prevention of parturient hypocalcemia. J. Dairy Sci. 64:217-226.

Greene, L. W., J. P. Fontenot, and K. E. Webb Jr.. 1983a. Effect of dietary potassium on absorption of magnesium and other macroelements in sheep fed different levels of magnesium. J. Anim. Sci. $56: 1208-1213$.

Greene, L. W., J. P. Fontenot, and K. E. Webb Jr.. 1983b. Site of magnesium and other macromineral absorption in steers fed high levels of potassium. J. Anim. Sci. 57:503-510.

Greene, L. W., K. E. Webb Jr., and J. P. Fontenot. 1983c. Effect of potassium level on site of absorption of magnesium and other macroelements in sheep. J. Anim. Sci. 56:1214-1221.

Haaland, G. L., and H. F. Tyrrell. 1982. Effects of limestone and sodium bicarbonate buffers on rumen measurements and rate of passage in cattle. J. Anim. Sci. 55:935-942.

Hall, M. B. 2009. Determination of starch, including maltooligosaccharides, in animal feeds; comparison of methods and a method recommended for AOAC collaborative study. J. AOAC Int. 92:42-49.

House, W. A., and A. W. Bell. 1993. Mineral accretion in the fetus and adnexa during late gestation in Holstein cows. J. Dairy Sci. 76:2999-3010.

Jesse, B. W., J. W. Thomas, and R. S. Emery. 1981. Availability of magnesium from magnesium oxide particles of different sizes and surfaces. J. Dairy Sci. 64:197-205.

Jittakhot, S., J. T. Schoneville, H. Wouterse, C. Yuangklang, and A. C. Beynen. 2004. Apparent magnesium absorption in dry cows fed at 3 levels of potassium and 2 levels of magnesium intake. J. Dairy Sci. 87:379-385

Khorasani, G. R., R. A. Janze, W. B. McGill, and J. J. Kenelly. 1997. Site and extent of mineral absorption in lactating cows fed wholecrop cereal grain silage or alfalfa silage. J. Anim. Sci. 75:239-248.

Kronqvist, C., U. Emanuelson, R. Sporndly, and K. Holtenius. 2011. Effects of prepartum dietary calcium level on calcium and magnesium metabolism in periparturient dairy cows. J. Dairy Sci. 94:1365-1373.

Lean, I. J., P. J. DeGaris, D. M. McNeil, and E. Block. 2006. Hypocalcemia in dairy cows: Meta-analysis and dietary cation anion difference theory revisited. J. Dairy Sci. 89:669-684.

Leno, B. M., C. M. Ryan, T. Stokol, D. Kirk, K. P. Zanzalari, J. D. Chapman, and T. R. Overton. 2017. Effects of prepartum dietary cation-anion difference on aspects of peripartum mineral and energy metabolism and performance of multiparous Holstein cows. J. Dairy Sci. 100:4604-4622.

Littell, R. C., G. A. Milliken, W. W. Stroup, and R. D. Wolfinger. 1996. SAS System of Mixed Models. SAS Institute, Cary, NC.

Martinez, N., C. A. Risco, F. S. Lima, R. S. Bisinotto, L. F. Greco, E. S. Ribeiro, F. Maunsell, K. Galvao, and J. E. Santos. 2012. Evaluation of peripartal calcium status, energetic profile, and neutrophil function in dairy cows at low or high risk of developing uterine disease. J. Dairy Sci. 95:7158-7172.

Martinez, N., L. D. Sinedino, R. S. Bisinotto, R. Daetz, C. Lopera, C. A. Risco, K. N. Galvao, W. W. Thatcher, and J. E. Santos. 2016. Effects of oral calcium supplementation on mineral and acid-base status, energy metabolites, and health of postpartum dairy cows. J. Dairy Sci. 99:8397-8416.

Moore, W. F., J. P. Fontenot, and R. E. Tucker. 1971. Relative effects of different supplemental magnesium sources on apparent digestibility in steers. J. Anim. Sci. 33:502-506.

NRC. 2001. Nutrient Requirements of Dairy Cattle. 7th rev. ed. Natl. Acad. Press, Washington, DC.

Olmos Colmenero, J. J., and G. A. Broderick. 2006. Effect of dietary crude protein concentration on milk production and nitrogen utilization in lactating dairy cows. J. Dairy Sci. 89:1704-1712.

Penner, G. B., K. A. Beauchemin, and T. Mutsvangwa. 2007. Severity of ruminal acidosis in primiparous Holstein cows during the periparturient period. J. Dairy Sci. 90:365-375.
Peterson, A. B., M. W. Orth, J. P. Goff, and D. K. Beede. 2005. Periparturient responses of multiparous Holstein cows fed different dietary phosphorus concentrations prepartum. J. Dairy Sci. 88:3582-3594

Rahnema, S. H., and J. P. Fontenot. 1983. Effect of supplemented magnesium from magnesium oxide or dolomitic limestone upon digestion and absorption of minerals in sheep. J. Anim. Sci. 57:15451552.

Ramberg, C. F., Jr., G. P. Mayer, D. S. Kronfeld, J. M. Phang, and M. Berman. 1970. Calcium kinetics in cows during late pregnancy parturition and early lactation. Am. J. Physiol. 219:1166-1177.

Ramos-Nieves, J. M., B. J. Thering, M. R. Waldron, P. W. Jardon, and T. R. Overton. 2009. Effects of anion supplementation to lowpotassium prepartum diets on macromineral status and performance of periparturient dairy cows. J. Dairy Sci. 92:5677-5691.

Reinhardt, T. A., J. D. Lippolis, B. J. McCluskey, J. P. Goff, and R. L. Horst. 2011. Prevalence of subclinical hypocalcemia in dairy herds. Vet. J. 188:122-124.

Roberts, T., N. Chapinal, S. J. Leblanc, D. F. Kelton, J. Dubuc, and T. F. Duffield. 2012. Metabolic parameters in transition cows as indicators for early-lactation culling risk. J. Dairy Sci. 95:30573063.

Rude, R. K., J. S. Adams, E. Ryzen, D. B. Endres, H. Nimi, R. L. Horst, J. G. Haddad Jr., and F. R. Singer. 1985. Low serum concentrations of 1,25-dihydroxyvitamin $\mathrm{D}$ in human magnesium deficiency. J. Clin. Endocrinol. Metab. 61:933-940.

Rude, R. K., S. B. Oldham, C. F. Sharp Jr., and F. R. Singer. 1978. Parathyroid hormone secretion in magnesium deficiency. J. Clin. Endocrinol. Metab. 47:800-806.

Schaefer, D. M., L. J. Wheeler, C. H. Noller, R. B. Keyser, and J. L. White. 1982. Neutralization of acid in the rumen by magnesium oxide and magnesium carbonate. J. Dairy Sci. 65:732-739.

Shappell, N. W., J. H. Herbein, L. J. Deftos, and R. J. Aiello. 1987. Effects of dietary calcium and age on parathyroid hormone, calcitonin and serum and milk minerals in the periparturient dairy cow. J. Nutr. 117:201-207.

Shook, G. E. 1993. Genetic improvement of mastitis through selection on somatic cell count. Vet. Clin. North Am. Food Anim. Pract. 9:563-581.

Tsioulpas, A., A. S. Grandison, and M. J. Lewis. 2007. Changes in physical properties of bovine milk from the colostrum period to early lactation. J. Dairy Sci. 90:5012-5017.

Tyrrell, H. F., and J. T. Reid. 1965. Prediction of the energy value of cow's milk. J. Dairy Sci. 48:1215-1223.

van Mosel, M., A. T. van 't Klooster, and H. S. Wouterse. 1991. Effects of a deficient magnesium supply during the dry period on bone turnover of dairy cows at parturition. Vet. Q. 13:199-208.

van Mosel, M., A. T. van't Klooster, and A. Malestein. 1990. Effects of an inadequate dietary intake of magnesium on osteogenesis in dairy cows during the dry period. Res. Vet. Sci. 48:280-287.

Van Ravenswaay, R. O., P. R. Henry, C. B. Ammerman, and R. C. Littell. 1989. Comparison of methods to determine relative bioavailability of magnesium in magnesium oxides for ruminants. J. Dairy Sci. 72:2968-2980.

Van Soest, P. J., J. B. Robertson, and B. A. Lewis. 1991. Methods for dietary fiber, neutral detergent fiber, and nonstarch polysaccharides in relation to animal nutrition. J. Dairy Sci. 74:3583-3597.

Weiss, W. P. 2004. Macromineral digestion by lactating dairy cows: Factors affecting digestibility of magnesium. J. Dairy Sci. 87:21672171.

Xin, Z., W. B. Tucker, and R. W. Hemken. 1989. Effect of reactivity rate and particle size of magnesium oxide on magnesium availability, acid-base balance, mineral metabolism, and milking performance of dairy cows. J. Dairy Sci. 72:462-470.

Yano, H., H. Matsui, and R. Kawashima. 1979. Effects of dietary calcium levels on concentration and solubility of macro minerals in the digestive tract of sheep. J. Anim. Sci. 48:954-960. 